\title{
A INCONSTITUCIONALIDADE DA VAQUEJADA E O EFEITO BACKLASH: UMA ANÁLISE DO JULGAMENTO DA ADI 4983
}

\author{
THE UNCONSTITUTIONALITY OF VAQUEJADA AND THE BACKLASH EFFECT: AN \\ ANALYSIS OF THE JUDGMENT OF ADI 4983
}

\section{Lucas Afonso Bompeixe Carstens}

Bacharel em Direito pela Universidade Federal do Paraná. Especialista em Ministério Público - Estado Democrático de Direito pela Fundação Escola do Ministério Público do Paraná e especializando em Direito Animal pela UNINTER. Advogado e membro do Grupo de Trabalho em Direito Animal da OAB/PR.

Email: lucass90@gmail.com.

\section{Vicente de Paula Ataíde Junior}

Pós-Doutor em Direito pela Universidade Federal da Bahia. Doutor e Mestre em Direito pela Universidade Federal do Paraná. Professor Adjunto do Departamento de Direito Civil e Processual Civil da UFPR. Professor dos Programas de Pós-Graduação em Direito da UFPR. Juiz Federal em Curitiba.

E-mail: vicente.junior@ufpr.br

Recebido em: 02/07/2020

Aprovado em: 23/04/2021

RESUMO: O presente artigo tem por objetivo analisar o julgamento da ADI 4983, pelo Supremo Tribunal Federal, que resultou na declaração da inconstitucionalidade de lei cearense que pretendia regular a prática da vaquejada. Para tanto, faz-se, inicialmente, um resgate histórico dessa manifestação cultural, demonstrando a forma pela qual a vaquejada é realizada. Após, evidenciada a execução da vaquejada, verifica-se que se trata de uma prática intrinsecamente cruel, impondo sofrimento físico e mental aos animais. Na sequência, mostram-se os principais argumentos invocados pelos Ministros da Corte Suprema, sejam a favor ou contra a declaração de inconstitucionalidade da lei. Prosseguindo, expõe-se a razão pela qual deve prevalecer a norma que veda a crueldade contra os animais, em detrimento da norma que garante manifestações culturais. Por último, destaca-se o efeito backlash à decisão da jurisdição constitucional, por meio da entrada em vigor da Emenda Constitucional 96/2017 e da Lei 13.364/2016, como forma de superação jurisprudencial por meio de reação legislativa. Conclui-se que essa decisão representa, pela crítica ao antropocentrismo e pelo consequente apelo ao biocentrismo, uma direção a ser seguida nos mais variados casos em que os seres humanos instrumentalizam os animais e, por consequência, desconsideram sua dignidade inerente como seres sencientes, fundamento a partir do qual se eleva o Direito Animal brasileiro. Para tanto, utiliza-se a metodologia indutiva, por meio de estudo de caso e consequente pesquisa teórica e bibliográfica pertinentes ao tema.

Palavras-chave: Vaquejada. Manifestação cultural. Crueldade contra animais. Efeito backlash. ADI 4983. Direito Animal.

ABSTRACT: This article aims to analyze the judgment of ADI 4983 by the Federal Supreme Revista de Direito Brasileira | Florianópolis, SC | v. 28 | n. 11 | p.80-103 | Jan./Abr. 2021 
Court, which resulted in the declaration of unconstitutionality of Ceará law that intended to regulate the practice of vaquejada. To this end, it is initially made a historical rescue of this cultural manifestation, demonstrating the way in which the vaquejada is performed. After evidencing the execution of vaquejada, it turns out that it is an intrisincally cruel practice, imposing physical and mental suffering on animais. After that, the main arguments put forward by the Ministers of the Supreme Court, either for or againt the declaration of unconstitucionality of the law. Going forward, it's shown the reason why the rule that prohibits cruelty to animals prevail over the rule that guarantees cultural manifestations. Finally, it's highlighted the backlash effect of the decision of the constitucional jurisdiction, through the entry into force of Constitucional Amendment 96/2017 and the Federal Law 13.364/2016, as a way of overcoming jurisprudence through legislative reaction. It is concluded that this decision representes, by criticizing anthropocentrism and the consequente appeal to biocentrism, a direction to be followed in the most varied cases in which human beings instrumentalize animals and, consequently, disregard their inherent dignity as sentient beings, the foundation from which the Brazilian Animal Law rises. For this, the inductive methodology is used, through a case study and consequente theoretical and bibliographic research relevant to the theme.

Keywords: Vaquejada. Cultural manifestation. Cruelty againt animals. Backlash effect. ADI 4983. Animal Law.

SUMÁRIO: Introdução. 1 Vaquejada: origens e características da atividade. 2 A crueldade na vaquejada: diálogo com a Medicina Veterinária. 3 O julgamento da ADI 4983: argumentos e contra-argumentos. 4 Da prevalência da norma que veda a crueldade contra os animais sobre a norma que garante a manifestação cultural. $5 \mathrm{O}$ efeito backlash e a proibição da vaquejada. Conclusões. Referências.

\section{INTRODUÇÃO}

Considerada como uma manifestação cultural do nordeste brasileiro, a vaquejada enfrenta diversas críticas por parte das organizações que defendem os animais, tendo em vista a submissão dos animais à crueldade.

Esse embate chegou ao Supremo Tribunal Federal, através da ação direta de inconstitucionalidade (ADI) 4.983, ajuizada pela Procuradoria-Geral da República, em razão da Lei 15.299/2013, do Estado do Ceará, a qual regulamentava, no âmbito estadual, a prática da vaquejada.

O Supremo Tribunal Federal, por maioria de votos (6x5), decidiu que a lei cearense da vaquejada contraria a Constituição Federal de 1988, tendo em vista a crueldade intrínseca contra animais. Apesar de ser uma atividade de longa data, a vaquejada provoca sofrimento físico e mental aos animais, atestado por laudos veterinários, razão pela qual deve prevalecer, na colisão de normas constitucionais no caso concreto, a norma que veda a crueldade contra os animais sobre a norma que protege as manifestações culturais.

Logo após essa decisão, contudo, produziu-se o efeito backlash à jurisdição constitucional, quando o Poder Legislativo, para superar a decisão da Suprema Corte, editou lei ordinária e emendou a Constituição, a fim de manter a prática da vaquejada e das suas atividades similares. Nesse sentido, encontra-se atualmente em vigor a Lei 13.364/2016, a qual eleva a vaquejada e o rodeio, bem como as respectivas expressões artístico-culturais, à condição de manifestações da cultura nacional e de patrimônio cultural imaterial. Da mesma forma, o art. 225 da Constituição Federal passou a contar com um parágrafo $7^{\circ}$, incluído pela EC 96/2017, o qual define que não se consideram cruéis as práticas desportivas que utilizem animais, desde que sejam manifestações culturais e registradas como bem de natureza imaterial integrante do patrimônio 
cultural brasileiro, as quais devem ser regulamentadas por lei específica que assegure o bem-estar dos animais envolvidos.

Nesse panorama, partindo-se de noções gerais sobre a vaquejada e de posicionamentos de médicos veterinários sobre a crueldade inerente a esta prática, o artigo discorre minunciosamente sobre os principais argumentos utilizados pelos ministros do STF quando do julgamento da ADI 4.983. Verificou-se que, nessa emblemática decisão, se assentou que os animais sencientes possuem dignidade e valor moral intrínseco, razão pela qual a crueldade contra os animais não deve ser tolerada, ainda que se trate de uma manifestação cultural de tempos imemoriais, promovida cada vez mais por nítidos interesses econômicos, como é o caso da vaquejada.

Para tanto, o presente artigo adota a metodologia indutiva, por meio de estudo de caso (especificamente o julgamento da ADI 4.983) e consequente revisão teórica e bibliográfica pertinentes ao tema em comento, evidenciando, por conseguinte, esse novo campo do saber jurídico que é o Direito Animal.

Ao final, são sumarizadas algumas conclusões com forte apelo prático, visando a auxiliar o desenvolvimento de novas pesquisas e indagações sobre a temática.

\section{VAQUEJADA: ORIGENS E CARACTERÍSTICAS DA ATIVIDADE}

Oriunda do nordeste brasileiro, a história da vaquejada remonta aos tempos antigos em os animais viviam soltos no sertão, sem qualquer restrição de espaço por meio de cercas. Desse modo, os coronéis começaram a contratar vaqueiros, para que estes, montados em seus cavalos, fossem atrás dos bois dispersos pelo campo. Apesar das dificuldades pelo caminho, os vaqueiros perseguiam, laçavam e traziam os bois ao coronel. Com o tempo, essa atividade serviu para mostrar as habilidades e a bravura desses vaqueiros na apreensão dos bois, o que fez surgir a ideia da realização de competição e disputas. ${ }^{1}$

Atualmente, de acordo com o regulamento geral da Associação Brasileira de Vaquejada $(\mathrm{ABVAQ})^{2}$, a vaquejada pode ser definida como "atividade cultural-competitiva, com características de esporte, praticado em uma pista sobre um colchão de areia com espessura mínima não inferior a $40 \mathrm{~cm}$, no qual dois vaqueiros montados a cavalo têm o objetivo de alcançar e emparelhar o boi entre os cavalos, conduzi-lo até o local indicado, onde o bovino deve ser deitado."3

Nessa atividade, a dupla de vaqueiros tem funções distintas, pois enquanto o vaqueiroesteireiro promove o direcionamento do boi até o local da faixa, de forma a emparelhá-lo junto ao vaqueiro-puxador ${ }^{4}$, este, recebendo o protetor de cauda do boi daquele, deve entrelaçar o referido protetor entre as mãos, puxando o boi pela cauda, a fim de fazê-lo cair na faixa demarcada no colchão de areia ${ }^{5}$. Se a operação tem êxito, isto é, se ocorre o tombamento do boi dentro da faixa de pontuação, formadas por "linhas paralelas, com distância de 9 metros entre uma e outra,

\footnotetext{
1 ASSOCIAÇÃO BRASILEIRA DE VAQUEJADA. História da Vaquejada. Disponível em: <http://www.abvaq.com.br/institucional>. Acesso em: 10 nov. 2019.

${ }^{2}$ Para fins do presente artigo, utilizou-se as definições trazidas no atual regulamento geral de vaquejada (2017-2018), documento que foi assinado em 29 de dezembro de 2016, em João Pessoa/PB, que visa a unificar as regras da vaquejada em todo o Brasil, via Associação Brasileira de Vaquejada (ABVAQ), estabelecendo normas de realização dos eventos, de bem-estar animal, além de definir procedimentos e estabelecer diretrizes garantidoras do bom andamento do esporte, através do controle e prevenção sanitário-ambientais, higiênicos-sanitárias e de segurança em geral.

${ }^{3}$ Art. $3^{\circ}$, item 1 do regulamento geral de vaquejada. Disponível em: <https://abvaq.com.br/regulamento>. Acesso em: 30 jun. 2020.

${ }^{4}$ Art. $3^{\circ}$, item 3 do regulamento geral de vaquejada. Disponível em: <https://abvaq.com.br/regulamento>. Acesso em: 30 jun. 2020.

${ }^{5}$ Art. $3^{\circ}$, item 2 do regulamento geral de vaquejada. Disponível em: <https://abvaq.com.br/regulamento〉. Acesso em: 30 jun. 2020.
}

Revista de Direito Brasileira | Florianópolis, SC | v. 28 | n. 11 | p.80-103 | Jan./Abr. 2021 
demarcadas sobre o colchão de areia, onde o boi deve ser deitado" ", o árbitro declara a expressão "valeu boi"7, o que significa que a dupla pontuou. Caso contrário, fala-se "zero boi", o que significa que a dupla não pontuou.

Nota-se que o regulamento atual da vaquejada tem pretensões de garantir o "bem-estar" dos animais durante o evento, estabelecendo que os animais, equinos e bovinos, devem ser sempre tratados de "forma humanitária", com dignidade, respeito e compaixão. ${ }^{9}$ Assim, tornou-se obrigatória a presença de um "juiz do Bem-Estar Animal", o qual tem, como função, a fiscalização das práticas adotadas em relação aos animais. ${ }^{10}$ Dentre as regras visando à proteção da integridade física dos animais, o atual regulamento, impulsionado pela decisão da inconstitucionalidade da vaquejada, prevê que esta não pode ser realizada sem o protetor de cauda. ${ }^{11}$ Por outro lado, verificando-se maus-tratos aos animais, de forma proposital, prevê-se a responsabilização do agressor. $^{12}$

Nesse contexto, a vaquejada é considerada, pelos seus defensores, como uma "prática cultural esportiva" (termo usado pela Associação Brasileira de Vaquejada ${ }^{13}$ ), por meio da qual uma dupla de vaqueiros tem a missão de puxar o boi pela cauda e derrubá-lo numa área delimitada, onde deve ficar com as quatro patas viradas para cima. ${ }^{14}$ Como "esporte", a vaquejada prevê regras próprias para a pontuação, classificação e disputa final dos vaqueiros, quando os vencedores são premiados ${ }^{15}$. Embora tenha como foco a competição dos vaqueiros, a vaquejada também atrai a população por conta da participação de artistas musicais, regionais ou nacionais, bem como pela presença de comércio no entorno (roupas e artigos de couro), leilões de equinos, entre outros, o que movimenta consideravelmente a economia local e regional. ${ }^{16}$

\section{A CRUELDADE NA VAQUEJADA: DIÁLOGO COM A MEDICINA VETERINÁRIA}

Conforme visto anteriormente, o regulamento geral da vaquejada (ABVAQ) tem uma série de disposições que, segundo seus adeptos, visam a assegurar o "tratamento humanitário" dos animais, tanto equinos, como bovinos, durante todo o evento.

\footnotetext{
${ }^{6}$ Art. $3^{\circ}$, item 4 do regulamento geral de vaquejada. Disponível em: <https://abvaq.com.br/regulamento>. Acesso em: 30 jun. 2020.

${ }^{7}$ Art. $3^{\circ}$, item 6 do regulamento geral de vaquejada. Disponível em: <https://abvaq.com.br/regulamento>. Acesso em: 30 jun. 2020.

${ }^{8}$ Art. $3^{\circ}$, item 7 do regulamento geral de vaquejada. Disponível em: <https://abvaq.com.br/regulamento>. Acesso em: 30 jun. 2020.

${ }^{9}$ Art. 41 do regulamento geral de vaquejada. Disponível em: <https://abvaq.com.br/regulamento>. Acesso em: 30 jun. 2020.

${ }^{10}$ Art. 41, item 2 do regulamento geral de vaquejada. Disponível em: 〈https://abvaq.com.br/regulamento>. Acesso em: 30 jun. 2020.

${ }^{11}$ Art. 40 do regulamento geral de vaquejada. Disponível em: 〈https://abvaq.com.br/regulamento〉. Acesso em: 30 jun. 2020.

12 Art. 38 do regulamento geral de vaquejada. Disponível em: 〈https://abvaq.com.br/regulamento>. Acesso em: 30 jun. 2020.

${ }^{13}$ Art. 39 do regulamento geral de vaquejada. Disponível em: <https://abvaq.com.br/regulamento>. Acesso em: 30 jun. 2020.

${ }^{14}$ DIAS, Edna Cardozo. A tutela jurídica dos animais. Belo Horizonte: Mandamentos, 2000, p. 201.

15 "Em uma competição, os vaqueiros podem ganhar prêmios vultosos, de um caminhão a um prêmio em dinheiro de até R \$ 500 mil. Em 2017, as 135 vaquejadas chanceladas pela Associação Brasileira de Vaquejada (ABVAQ) movimentaram R\$ 13 milhões só em premiação." (CONSELHO FEDERAL DE MEDICINA VETERINÁRIA. Desmistificar a vaquejada. Disponível em: < http://portal.cfmv.gov.br/noticia/index/id/5799/secao/6 >. Acesso em: 11 nov. 2019)

16 SENADO FEDERAL. Associação acredita poder mudar decisão do STF. Disponível em: <https://www12.senado.leg.br/emdiscussao/edicoes/vaquejada/vaquejada/associacao-acredita-poder-mudar-decisaodo-stf>. Acesso em: 11 nov. 2019.
}

Revista de Direito Brasileira | Florianópolis, SC | v. 28 | n. 11 | p.80-103 | Jan./Abr. 2021 
Nessa seara, contudo, o Direito precisa dialogar com outras ciências, para mais bem avaliar a justeza e adequação desses conceitos extrajurídicos. Nesse caso, a Medicina Veterinária, como ramo da ciência médica que se ocupa da saúde animal, é fundamental para a discussão.

O Conselho Federal da Medicina Veterinária (CFMV), em 2016, após o julgamento da ação direta de inconstitucionalidade, emitiu nota pública no sentido de ser contra a vaquejada e contra quaisquer outras atividades que causem sofrimento aos animais, destacando que o termo sofrimento "se refere a questões físicas tais como ferimentos, contusões ou fraturas, e a questões psicológicas, como imposição de situações que gerem medo, angústia ou pavor, entre outros sentimentos negativos. "17

De acordo com a Comissão de Ética, Bioética e Bem-Estar Animal do CFMV, então presidida pela Dra. Carla Forte Maiolino Molento, Professora do Departamento de Medicina Veterinária da Universidade Federal do Paraná, "o gesto brusco de tracionar violentamente o animal pelo rabo pode causar luxação das vértebras, ruptura de ligamentos e de vasos sanguíneos, estabelecendo lesões traumáticas com o comprometimento, inclusive, da medula espinhal." "18 Para a Comissão, "a queda violenta ocasionada durante a vaquejada pode resultar em contusões na musculatura do animal e lesões aos órgãos internos" ${ }^{19}$ e, mesmo que se pudesse evitar o sofrimento físico, ainda assim restaria configurado o sofrimento emocional dos bovinos, pois "o impedimento de fuga de uma ameaça exacerba reações límbicas de ansiedade, medo e desespero" "20 o que confirma o sofrimento emocional a que os bovinos são expostos na realização da vaquejada.

Ademais, outros estudos de especialistas no assunto têm demonstrado o sofrimento provocado aos animais durante a vaquejada.

Dentre eles, destaca-se o laudo técnico assinado pela Dra. Irvênia Luiza de Santis Prada, Mestre e Doutora em Anatomia dos Animais Silvestres e Domésticos pela Universidade de São Paulo, em conjunto com a Dra. Vânia de Fátima Plaza Nunes, Médica Veterinária Sanitarista e Diretora Técnica do Fórum Nacional de Proteção e Defesa e Animal, pelo qual se demonstraram, em detalhes, o sofrimento físico e mental que são comuns aos animais na vaquejada. Pela referência na comunidade científica, esse laudo foi utilizado pela ProcuradoriaGeral da República para embasar o pedido de inconstitucionalidade da lei cearense da vaquejada perante o Supremo Tribunal Federal.

Confira-se um extrato do documento:

Ao perseguirem o bovino, os peões acabam por segurá-lo fortemente pela cauda (rabo), fazendo com que ele estanque e seja contido. A cauda dos animais é composta, em sua estrutura óssea, por uma sequiência de vértebras, chamadas coccígeas ou caudais, que se articulam umas com as outras. Nesse gesto brusco de tracionar violentamente o animal pelo rabo, é muito provável que disto resulte luxação das vértebras, ou seja, perda da condição anatômica de contato de uma com a outra. Com essa ocorrência, existe a ruptura de ligamentos e de vasos sangüíneos, portanto, estabelecendo-se lesões traumáticas. Não deve ser rara a

\footnotetext{
${ }^{17}$ AGÊNCIA DE NOTÍCIAS DE DIREITOS ANIMAIS. Conselho Federal de Medicina Veterinária se posiciona contra vaquejadas. Disponível em: < https://www.anda.jor.br/2016/10/conselho-federal-de-medicina-veterinaria-seposiciona-contra-vaquejadas/> Acesso em: 17 nov. 2019.

${ }^{18}$ AGÊNCIA DE NOTÍCIAS DE DIREITOS ANIMAIS. Conselho Federal de Medicina Veterinária se posiciona contra vaquejadas. Disponível em: < https://www.anda.jor.br/2016/10/conselho-federal-de-medicina-veterinaria-seposiciona-contra-vaquejadas/> Acesso em: 17 nov. 2019.

${ }^{19}$ AGÊNCIA DE NOTÍCIAS DE DIREITOS ANIMAIS. Conselho Federal de Medicina Veterinária se posiciona contra vaquejadas. Disponível em: < https://www.anda.jor.br/2016/10/conselho-federal-de-medicina-veterinaria-seposiciona-contra-vaquejadas/> Acesso em: 17 nov. 2019.

${ }^{20}$ AGÊNCIA DE NOTÍCIAS DE DIREITOS ANIMAIS. Conselho Federal de Medicina Veterinária se posiciona contra vaquejadas. Disponível em: < https://www.anda.jor.br/2016/10/conselho-federal-de-medicina-veterinaria-seposiciona-contra-vaquejadas/> Acesso em: 17 nov. 2019.
}

Revista de Direito Brasileira | Florianópolis, SC | v. 28 | n. 11 | p.80-103 | Jan./Abr. 2021 
desinfeção (arrancamento) da cauda, de sua conexão com o tronco. Como a porção caudal da coluna vertebral representa continuação dos outros segmentos da coluna vertebral, particularmente na região sacral, afecções que ocorrem primeiramente nas vértebras caudais podem repercutir mais para frente, comprometendo inclusive a medula espinhal que se acha contida dentro do canal vertebral. Esses processos patológicos são muito dolorosos, dada a conexão da medula espinhal com as raízes dos nervos espinhais, por onde trafegam inclusive os estímulos nociceptivos (causadores de dor). Volto a repetir que além de dor física, os animais submetidos a esses procedimentos vivenciam sofrimento mental. A estrutura dos eqüinos e bovinos é passível de lesões na ocorrência de quaisquer procedimentos violentos, bruscos e/ou agressivos, em coerência com a constituição de todos os corpos formados por matéria viva. Por outro lado, sendo o "cérebro", o órgão de expressão da mente, a complexa configuração morfofuncional que exibe em eqüinos e bovinos é indicativa da capacidade psíquica desses animais, de aliviar e interpretar as situações adversas a que são submetidos, disto resultando sofrimento. ${ }^{21}$

Esse laudo demonstra as sequelas comumente sofridas pelos animais durante a vaquejada, não havendo dúvidas de que os animais sofrem física e psiquicamente, donde se conclui se tratar de prática cruel.

A Associação Brasileira de Medicina Veterinária Legal, em 24 de outubro de 2016, endossou o citado laudo técnico, afirmando que "constitui em verdadeira prova material, demonstrando, de maneira clara e detalhada, que os animais envolvidos na prática da vaquejada de fato experimentam dor, sofrimento, estresse e maus-tratos" 22 , razão pela qual, em nota pública, manifestou apoio irrestrito a posição do Supremo Tribunal Federal, no julgamento da ADI 4.983.

Ainda que as condições dos bovinos sejam as mais destacadas e chamem mais a atenção, não se pode olvidar que a vaquejada é também uma prática agressiva aos equinos utilizados pelos competidores, submetendo-os a intensos esforços físicos e imposições estressantes, conforme demonstram estudos científicos. ${ }^{23}$

Foi o julgamento da vaquejada no Supremo Tribunal Federal que induziu a Associação Brasileira de Vaquejada a estabelecer novas normas de condutas durante a atividade, incluindo,

\footnotetext{
${ }^{21}$ Parecer técnico, de 25 de julho de 1990, emitido pela Dra. Irvênia Luiza de Santis Prada, apud LEITÃO, Geuza. A voz dos sem voz. Fortaleza: INESP, 2002. p. 23.

22 ASSOCIAÇÃO BRASILEIRA DE MEDICINA VETERINÁRIA LEGAL. Nota pública quanto à inconstitucionalidade da vaquejada. Disponível em: <http://www.abmvl.org.br/single-post/2016/10/24/ABMVL\%E2\%80\%93-NOTA-P\%C3\%9ABLICA-QUANTO-\%C3\%80-INCONSTITUCIONALIDADE-DA-

VAQUEJADA>. Acesso em: 19 nov. 2019.

${ }^{23}$ Nesse sentido, um estudo feito antes e depois da apresentação dos equinos asseverou que "Os equinos de vaquejada avaliados apresentaram alterações físicas, bioquímicas e hematológicas em decorrência do exercício e do estresse a que foram submetidos. Assim, pode-se sugerir que os equinos de vaquejada avaliados apresentaram alterações físicas, bioquímicas e hematológicas em decorrência do estresse associado ao exercício físico, à falta de uma rotina de treinamento adequado e às condições ambientais inóspitas dos parques de vaquejada." (LOPES, K. R. F.; BATISTA, J.; DIAS, R. V. C; BLANCO, B. S.. Influência das competições de vaquejada sobre os parâmetros indicadores de estresse em equinos. Ciência Animal Brasileira, (UFG), v. 10, p. 545-550, 2009. p. 542).
} 
dentre outras medidas, a obrigatoriedade do uso do protetor de cauda ${ }^{2425}$ e a inclusão do colchão de areia na área em que o boi deve ser derrubado, a fím de amortecer a queda. ${ }^{26}$

Mesmo com essa "modernização da vaquejada", no intuito declarado de se garantir o "bem-estar animal", a Dra. Irvênia Luiza de Santis Prada mantém a sua opinião técnica no sentido de não ser possível a realização dessa atividade sem que os animais sofram, asseverando que isso apenas confirma, por parte de seus defensores, que a violência é intrínseca à prática. Nas incisivas palavras da Professa da USP:

Os próprios defensores da vaquejada admitem a vivência de sofrimento nos animais, ao argumentarem que a regulamentação do evento possa "minimizar" os riscos dos animais. Apetrechos como protetor de cauda, luvas e colchões são recursos utilizados mais para aliviar a consciência dos praticantes -ou para "venderem" a imagem de que são cuidadosos-, do que de fato para suprimir o sofrimento dos animais. ${ }^{27}$

Desse modo, nem mesmo a tentativa dos que lucram com a vaquejada, em garantir o bem-estar dos animais durante a citada prática pode, de fato, evitar o sofrimento vivenciado pelos animais. É dizer, com outras palavras, que não existe uma maneira mais branda ou mais amena de tracionar a cauda de um animal pesado e derrubá-lo numa área delimitada, mesmo usando-se o "protetor de cauda". A vaquejada, portanto, é atividade intrinsecamente hostil e violenta aos animais. $\mathrm{O}$ animal é tratado como coisa, como um mero objeto para o lucrativo entretenimento humano. Não existe benefício para o animal, acuado e vilipendiado em um ambiente repleto de medo, dor e angústia.

A decisão do Supremo Tribunal Federal sobre a inconstitucionalidade da lei cearense da vaquejada foi baseada nas análises científicas e nos diálogos com a Medicina Veterinária. Sem os laudos, estudos e pareceres técnico-veterinários, certamente os Ministros do STF não teriam a segurança para afirmar que a vaquejada discrepa da regra constitucional que proíbe a crueldade. Para dizer que a crueldade é intrínseca à vaquejada e que esta atividade, por sua própria natureza, não é compatível com a Constituição, foi indispensável um cotejo interdisciplinar, para além do conhecimento jurídico.

\footnotetext{
${ }^{24} \mathrm{Na}$ vaquejada, é muito comum que o boi, muitas vezes utilizados em várias apresentações seguidas, tenha sua cauda arrancada quando o vaqueiro a puxa com força na área em que deve ser derrubado. Nesse sentido: BITTENCOURT, Mario. 'O boi teve o rabo arrancado': proibição da vaquejada abre polêmica. G1, Bahia. Disponível em: 〈http://g1.globo.com/bahia/noticia/2016/11/o-boi-teve-o-rabo-arrancado-proibicao-da-vaquejada-abrepolemica.html>. Acesso em: 19 nov. 2019.

${ }^{25}$ VIDEOPAR. Protetor de cauda para uso na vaquejada. Disponível em: <https://www.videopar.com.br/artigos/43-Protetor-de-Cauda-para-uso-na-Vaquejada>. Acesso em: 20 nov. 2019.

${ }^{26}$ Talvez em razão da adoção dessas novas medidas, - e muito provavelmente pelas pressões recebidas -, o Conselho Federal de Medicina Veterinária mudou sua posição inicial, ao publicar uma nota intitulada "desmistificar a vaquejada", em 08 de agosto de 2018, pela qual manifestou apoio a realização de competições que seguem as normas de bem-estar animal, a fim de que "as manifestações culturais ocorram sob o rigor da fiscalização e sejam, obrigatoriamente, supervisionadas por médicos veterinários ou zootecnistas, competentes para garantir o manejo adequado e o bem-estar dos animais envolvidos." (CONSELHO FEDERAL DE MEDICINA VETERINÁRIA. Desmistificar a vaquejada. Disponível em: < http://portal.cfmv.gov.br/noticia/index/id/5799/secao/6 $>$. Acesso em: 11 nov. 2019)

${ }^{27}$ AGÊNCIA DE NOTÍCIAS DE DIREITOS ANIMAIS. Vaquejada tem de ser proibida imediatamente. Disponível em: <https://www.anda.jor.br/2016/11/vaquejada-tem-de-ser-proibida-imediatamente-diz-veterinaria-dausp/>. Acesso em: 21 nov. 2019.
}

Revista de Direito Brasileira | Florianópolis, SC | v. 28 | n. 11 | p.80-103 | Jan./Abr. 2021 


\section{O JULGAMENTO DA ADI 4.983: ARGUMENTOS E CONTRA-ARGUMENTOS}

A ação direta de inconstitucionalidade 4.983, proposta pela Procuradoria-Geral da República, contra a Lei 15.299/2013, do Estado do Ceará, foi paradigmática por duas principais razões: (1) a consolidação do Direito Animal como disciplina autônoma e separada do Direito Ambiental; ${ }^{28}$ (2) a repercussão social e econômica, nitidamente contra-majoritária, que ensejou a produção do efeito backlash.

Para uma noção da sua cronologia, o julgamento foi iniciado em 12 de agosto de 2015, com o voto do relator, Ministro Marco Aurélio, pela procedência do pedido, ocasião em que também abriu-se a divergência, pelos votos dos Ministros Edson Fachin e Gilmar Mendes. Na sessão de 02 junho de 2016, os Ministros Luís Roberto Barroso, Rosa Weber e Celso de Mello votaram pela procedência, enquanto os Ministros Teori Zavascki e Luiz Fux votaram pela improcedência do pedido. Finalmente, em 06 de outubro de 2016, o Ministro Dias Toffoli votou pela improcedência do pedido, enquanto que o Ministro Ricardo Lewandowski e a Ministra Cármen Lúcia votaram pela procedência do pedido formulado pela Procuradoria-Geral da República.

Vale mencionar, de antemão, os argumentos invocados pelo Ministério Público Federal, representado, à época, pelo Procurador-Geral da República, Roberto Monteiro Gurgel Santos, para sustentar a inconstitucionalidade da Lei 15.299/2013, do Estado do Ceará.

$\mathrm{Na}$ petição inicial da demanda objetiva, foram pontuados os danos irreparáveis para os bovinos e equinos usados na realização da vaquejada, revelando, assim, a sua crueldade intrínseca, apesar de suas características culturais e desportivas. Foi lembrado que, nas situações em que se tem o conflito entre a norma que protege as manifestações culturais e a norma que veda a crueldade contra os animais, o Supremo Tribunal Federal tem se manifestado, no uso da técnica da ponderação, a favor desta última, vedando as práticas que condenam os animais a situações degradantes, razão pela qual a lei cearense seria inconstitucional. ${ }^{29}$

A fim de se compreender o debate no âmbito da jurisdição constitucional, sob os vários pontos de vista, vale a pena discorrer sobre os principais argumentos invocados pelos ministros do Supremo Tribunal Federal a respeito da vaquejada.

O Ministro Marco Aurélio, relator da ação direta de inconstitucionalidade, destacou que a questão trazida ao Supremo Tribunal Federal configurava um conflito de normas constitucionais sobre direitos fundamentais, de um lado, a norma que protege as manifestações culturais (art. 215 da $\mathrm{CF}$ ) e, de outro, a norma que veda as práticas que submetem os animais a crueldade (artigo 225, $\S 1^{\circ}$, inciso VII da CF) De acordo com Marco Aurélio, os laudos veterinários evidenciaram que a vaquejada submete os animais, bovinos e equinos, a uma crueldade intolerável.

Nas palavras do relator, o sentido do vocábulo crueldade "alcança, sem sombra de dúvida, a tortura e os maus-tratos infringidos aos bovinos durante a prática impugnada, revelando-se intolerável, a mais não poder, a conduta humana autorizada pela norma estadual atacada.".

Com outro ponto de vista, o Ministro Edson Fachin, ex-Professor do Departamento de Direito Civil e Processual Civil da Universidade Federal do Paraná, conferiu maior peso às manifestações e tradições culturais sobre a regra da proibição da crueldade envolvida na vaquejada. Para ele, a Constituição Federal não apenas valoriza as manifestações culturais, como também impõe ao Estado o dever de proteger as manifestações das culturas populares, indígenas e afro-

\footnotetext{
28 "O Direito Animal positivo é o conjunto de regras e princípios que estabelece os direitos fundamentais dos animais não-humanos, considerados em si mesmos, independentemente da sua função ambiental ou ecológica." (ATAIDE JUNIOR, Vicente de Paula. Introdução ao direito animal brasileiro. Revista Brasileira de Direito Animal, Salvador, v. 13, n. 3, p. 48-76, set./dez, 2018, p. 50. ISSN 2317-4552. Disponível em: 〈https://portalseer.ufba.br/index.php/RBDA/article/view/28768/17032〉. Acesso em: 14 dez. 2019. DOI: http://dx.doi.org/10.9771/rbda.v13i3.28768.

${ }^{29}$ STF, Pleno, ADI 4983, Relator Ministro MARCO AURÉLIO, julgado em 06/10/2016, publicado em 27/04/2017.
}

Revista de Direito Brasileira | Florianópolis, SC | v. 28 | n. 11 | p.80-103 | Jan./Abr. 2021 
brasileiras e das de outros grupos participantes do processo civilizatório nacional, conforme o seu artigo $215, \S 1^{\circ}$. Nesse sentido, no seu entender, não se deve apagar práticas culturais que fazem parte do processo civilizatório, tal qual a vaquejada, haja vista que esta atividade faz parte do "modo de criar, fazer e viver da população sertaneja".

Ainda, segundo Fachin, deve-se reconhecer a importância das manifestações culturais da população rural, o que só é possível se abandonarmos a visão unilateral que tem como parâmetro apenas a realidade urbana. Desse modo, considerando a vaquejada como legítima expressão da manifestação cultural de um povo e diante da incerteza a respeito da existência de crueldade imposta os animais - que seria diferente da farra do boi e da rinha de galo -, o Ministro manifestou que não se deve "proibir o evento e a competição, que reproduzem e avaliam tecnicamente a atividade de captura própria de trabalho de vaqueiros e peões, desenvolvida na zona rural deste grande país."

O Ministro Gilmar Mendes, por sua vez, perfilhando-se à divergência, reconheceu que a vaquejada carrega em si um "forte conteúdo cultural", não sendo a proibição dessa atividade o melhor caminho a ser adotado. É possível notar um forte apelo pragmático no seu voto. Segundo ele, deveria haver a adoção e o aperfeiçoamento das medidas que reduzam as chances do animal se lesionar. Defendeu, como Fachin, o pluralismo existente na sociedade e o reconhecimento de práticas culturais que fazem parte da história do Brasil, desde tempos longínquos, salientando a necessidade de apreciar as manifestações culturais com certa moderação, pois, do contrário, há o perigo de caírem na clandestinidade: além de tirar o lazer de muitas pessoas, declarar a inconstitucionalidade "resultaria em jogar na ilegalidade milhares de pessoas que se dedicam a essa atividade em caráter amador ou profissional."

O Ministro Luís Roberto Barroso apresentou um voto-vista: trata-se da manifestação judicial mais importante da história do Direito Animal brasileiro. ${ }^{30}$

Bastante didático e robusto, dividido em capítulos, Barroso destacou que a Constituição Federal de 1988, ao vedar as práticas que submetam os animais à crueldade, reconheceu que os animais não só são seres sencientes, como possuem o interesse em não sofrer. Além disso, nas suas palavras, "a tutela desse interesse não se dá, como uma interpretação restritiva poderia sugerir, tãosomente para a proteção do meio-ambiente, da fauna ou para a preservação das espécies", mas, ao contrário, "a proteção dos animais contra práticas cruéis constitui norma autônoma, com objeto e valor próprios", decorrente do sofrimento animal por si só.

Seguindo sua linha de raciocínio, o Ministro Barroso asseverou que a Assembleia Constituinte, ao reconhecer a existência de práticas cruéis contra os animais, impôs a vedação dessas práticas justamente para proteger os animais nessas situações, e não para se garantir um meio ambiente ecologicamente equilibrado e/ou propósitos preservacionistas. Para sustentar seu ponto de vista, defendeu que se o interesse fosse estritamente ecológico, tal norma seria desnecessária, pois a própria norma que veda as práticas cruéis contra os animais ressalta também o dever de "proteger a fauna" e, da mesma forma, afirmou ser incabível o argumento do propósito preservacionista, haja vista que, novamente, a norma que proíbe as práticas cruéis contra os animais também proíbe as práticas que "provoquem a extinção das espécies".

Considerando a crueldade como o ato de "intencionalmente causar significativo sofrimento a uma pessoa ou a outro ser senciente", o Ministro Barroso ressaltou que o ato cruel pode ser físico (em regra mais perceptível, "gera algum tipo de manifestação explícita de desconforto por parte de quem sente dor, seja um grito, uivo ou convulsão") ou mental (menos perceptível, é passível de ser experimentado pelos seres que possuem desenvolvimento neurológico, sendo certo que "inúmeros animais manifestam seu estado mental por meio de

\footnotetext{
${ }^{30}$ ATAIDE JUNIOR, Vicente de Paula. Introdução ao direito animal brasileiro. Revista Brasileira de Direito Animal, Salvador, v. 13, n. 3, p. 48-76, set./dez, 2018, p. 58. ISSN 2317-4552. Disponível em: <https://portalseer.ufba.br/index.php/RBDA/article/view/28768/17032〉. Acesso $\quad$ em: 14 dez. 2019.
} DOI: http://dx.doi.org/10.9771/rbda.v13i3.28768.

Revista de Direito Brasileira | Florianópolis, SC | v. 28 | n. 11 | p.80-103 | Jan./Abr. 2021 
comportamentos diversos, que vão da excitação à prostração"). Nessa perspectiva, o simples risco da ocorrência de um dano, fundado numa dúvida razoável, atrairia a aplicação do princípio da precaução a fim de evitar o resultado danoso.

Ao analisar como a vaquejada se opera, tendo em vista ainda os laudos veterinários apresentados, o voto-vista não deixou dúvidas de que se trata de prática cruel, tanto para os equinos quanto para os bovinos (nesse sentido, em uma observação após seu voto, deixou claro que viu dezenas de vídeos na internet sobre o evento da vaquejada, concluindo ser visível que os animais são vítimas de atos cruéis). Portanto, concluiu que a lei cearense que regulamentou a vaquejada violou a norma constitucional que veda submissão dos animais a tratamentos cruéis, entendendo, inclusive, ser impossível a regulamentação sobre os atos principais realizados pelos vaqueiros, eis que descaracterizaria completamente tal atividade.

$\mathrm{Na}$ sequência do julgamento, o Ministro Teori Zavascki, ex-Presidente do Tribunal Regional Federal da $4^{\mathrm{a}}$ Região, pontuou que a questão em julgamento não diz respeito à vaquejada em si, mas sim a uma lei que foi criada para regulamentar a vaquejada no Estado do Ceará. Por isso, no seu entender, a vaquejada pode ser cruel ou não cruel ao animal, e, havendo a possibilidade de não ser cruel, a prática da vaquejada não poderia ser considerada, de maneira definitiva, inconstitucional. Nesse ponto, reside a divergência de sua percepção com o argumento apresentado pelo Ministro Barroso, uma vez que, para esse último, a crueldade é inerente à vaquejada, tal como entendeu o Ministro Marco Aurélio.

Mesmo considerando a argumentação do Ministro Barroso, no sentido de não ser possível a realização da vaquejada sem a necessária submissão dos animais à crueldade, o Ministro Zavascki reforçou sua posição dizendo que, ainda que se declare a inconstitucionalidade de lei cearense, a vaquejada vai continuar a ser realizada nos Estados que a têm como uma das formas de manifestação cultural, de modo a ser preferível manter uma lei que ao menos regulamente essa prática. Da mesma maneira que o Ministro Gilmar Mendes, Teori Zavascki foi pragmático e consequencialista: "essa lei, bem ou mal, desnaturando ou não a vaquejada [...] busca evitar justamente a forma de vaquejada cruel. [...]. Sem esta lei, vamos ter vaquejada cruel."

Por seu turno, a Ministra Rosa Weber, aderindo aos votos dos Ministros Marco Aurélio e Luís Roberto Barroso, entendeu que a Constituição Federal de 1988, ao passo em que garante e incentiva as manifestações culturais, também repudia a crueldade contra os animais. Na visão da Ministra, fazendo-se o alinhamento das duas normas constitucionais, a conclusão não pode ser outra a não ser de que "o Estado não incentiva, nem garante manifestações culturais em que adotadas práticas cruéis contra os animais”.

Também a partir dos laudos veterinários juntados aos autos, a Ministra Rosa Weber concluiu que "não é possível coibir tal crueldade por meio de regulamentação, no caso da vaquejada". Indo mais além, Weber considerou que a norma constitucional que veda a submissão dos animais a tratamento cruel tem um viés biocêntrico, conferindo um valor intrínseco às outras formas de vidas não-humanas. Ressaltou-se que a Constituição veda os atos cruéis em si mesmos, o que significa que não há que se esperar o resultado "sangue e morte" do animal para a configuração do ato cruel, nem mesmo que se deve examinar o grau de sofrimento imposto, numa tentativa de graduá-lo. Com essa noção em mente, relembrou que, em casos similares, como no julgamento da farra do boi e da rinha de galo, a Corte Suprema associou a crueldade com o emprego de violência e, sendo assim, a vaquejada pode ser considerada violenta aos animais, eis que "o ato de pressionar - ou, no mínimo, enclausurar - o corpo do animal bovino entre os corpos de dois outros animais (cavalos, cuja integridade também resta comprometida com a prática), puxando-o pelo rabo - parte estruturante de seu corpo que representa a extensão da espinha dorsal - até que caia, é flagrantemente violento".

Muito importante para a autonomia do Direito Animal brasileiro e para o estabelecimento de direitos fundamentais animais, foi o reconhecimento explícito, por parte da Ministra Rosa Weber, da dignidade para além dos seres humanos, numa perspectiva abertamente pós-humanista. 
A dignidade animal, extraída por Weber do próprio texto constitucional, passa a exigir o estabelecimento legal de um catálogo mínimo de direitos fundamentais animais - os direitos fundamentais de $4^{a}$ dimensão, ${ }^{31}$ tal como o faz o Código de Direito e Bem-Estar Animal do Estado da Paraíba (Lei 11.140/2018). ${ }^{32}$

Por sua vez, o Ministro Luiz Fux inovou, em seu voto, ao introduzir seu raciocínio esboçando a trajetória de vida do boi até ser abatido para fins alimentares. Concluiu que o abate animal para consumo, realizado no Brasil, é o ato mais cruel perpetrado contra os animais, mas nem por isso tornou-se vedado, nos termos da Constituição Federal de 1988, sendo, em verdade, a alimentação um direito social. Com esse comparativo, votou contra a declaração da inconstitucionalidade da lei cearense da vaquejada, defendendo a "exploração dessa atividade cultural, com essas ponderações legislativas que afastam a crueldade da vaquejada, levando-se ainda em consideração que, com toda essa humanização, não há nada mais cruel do que o meio através do qual o povo se alimenta, com o abate do boi."

O Ministro Celso de Mello, a seu tempo, compreendeu que a lei cearense, ao regulamentar a vaquejada, gerou conflito ostensivo com a norma constitucional que não apenas protege a fauna, mas também veda as práticas que submetam os animais a crueldade. Além disso, relembrou que, no âmbito infraconstitucional, considera-se crime a prática de maus-tratos contra os animais, conforme reza o artigo 32 da Lei 9.605/1998. Por essa razão, assinalou que a vaquejada não pode simplesmente se cobrir no manto da manifestação cultural para ficar imune à aplicação da norma constitucional que veda as práticas cruéis contra os animais. Nesse sentido, relembrou a posição uniforme do Supremo Tribunal Federal no caso da farra do boi e da rinha de galo, as quais, por se revelarem cruéis aos animais, foram declaradas inconstitucionais pela corte, devendo-se, assim, aplicar esse mesmo entendimento no caso da vaquejada, dada sua crueldade intrínseca.

Nessa esteira, Celso de Mello foi além, afirmando que o sofrimento desnecessário dos animais "não constitui expressão de atividade cultural, pois isso repugna aos padrões civilizatórios que informam as formações sociais contemporâneas, eis que a sujeição da vida animal a experiências de crueldade não é compatível com a Constituição do Brasil."

Acompanhando a divergência, o Ministro Dias Toffoli compreendeu que a vaquejada é um importante acontecimento para os vaqueiros do nordeste, pois, além de ser um evento festivo e esportivo, contribui para o desenvolvimento social e econômico da região. Embora reconheça que a crueldade contra os animais não deva ser tolerada, sendo esse o entendimento do Supremo Tribunal Federal quando do julgamento da prática da farra do boi e da rinha de galo, Toffoli, por outro lado, declarou que a vaquejada, em particular, distingue-se daqueles dois precedentes. Isso porque, na sua percepção, na farra do boi não se exigem técnicas ou treinamentos específicos, enquanto na vaquejada a lei exige que os vaqueiros sejam profissionais habilitados, e, da mesma forma, na rinha de galo, a situação dos animais nessa prática exigia uma preparação prévia cruel, justamente para chegarem na arena de combate com o instinto de matar.

Dessa maneira, o Ministro Dias Toffoli pontuou que a vaquejada nunca foi regulamentada, mas quando se tornou regulamentada pela lei cearense foi alvo de ação direta de inconstitucionalidade. Assim sendo, por não verificar que a vaquejada imprime necessariamente crueldade contra os animais - não havendo, no seu entender, prova cabal nesse sentido -, entendeu que a prática da vaquejada, da forma regulamentada pela lei cearense, não entra em conflito com a norma constitucional que veda o tratamento cruel contra os animais, razão pela qual julgou improcedente a ação direta de inconstitucionalidade.

Com outra visão, o Ministro Ricardo Lewandowski iniciou seu voto com a consideração de que a norma constitucional que veda a crueldade contra os animais possui, na sua ótica, um viés

\footnotetext{
${ }^{31}$ ATAIDE JUNIOR, Vicente de Paula. A afirmação histórica do Direito Animal no Brasil. Revista Internacional de Direito Ambiental. v. VIII, n. 22, p. 295-332. jan./abr. 2019. p. 302.

${ }^{32}$ Cf. ATAIDE JUNIOR, Vicente de Paula (coord.). Comentários ao Código de Direito e Bem-Estar Animal do Estado da Paraíba: a positivação dos direitos fundamentais animais. Curitiba: Juruá, 2019.
} 
biocêntrico. Relembrou, nesse sentido, que a Carta da Terra, idealizada pela Comissão Mundial sobre Meio Ambiente e Desenvolvimento das Nações Unidas, e subscrita pelo Brasil, tem como um de seus princípios o reconhecimento de que todos os seres vivos possuem valor, independentemente de sua utilidade para os seres humanos.

Desse modo, "em contraposição a uma perspectiva antropocêntrica, que considera os animais como 'coisas', desprovidos de emoções, sentimentos ou quaisquer direitos", Lewandowski reiterou sua posição no sentido de que o ser humano deve respeitar todos os seres vivos em sua completa alteridade, sendo esse o sentido da norma constitucional que protege a fauna, votando pela procedência do pedido.

Finalmente, a Ministra Cármen Lúcia, na condição de Presidente do Supremo Tribunal Federal, declarou que o tema sob análise exigia de todos um estudo aprofundado, não só da leitura da forma como a vaquejada se realiza, mas também da visualização de vídeos que mostram efetivamente, na prática, o "espetáculo da vaquejada". Por tudo que leu e viu, a conclusão da Ministra é a de que a vaquejada se trata de uma manifestação extremamente agressiva aos animais, o que evidentemente entra em conflito com o desejado marco civilizatório que preserva a vida e rechaça a violência, considerando os preceitos enunciados pela Constituição Federal.

Embora reconhecesse que a vaquejada se trata de uma manifestação cultural de longo tempo, a Ministra Cármen Lúcia também entendeu que a cultura não é algo estático, mas suscetível de mudanças, sendo claro que "muitas culturas foram levadas nesta condição até que houvesse um outro modo de ver a vida." Apesar dos argumentos em sentido oposto, de que a lei cearense buscou garantir o bem-estar dos animais durante a vaquejada, na visão da Ministra não restou claro que esse tratamento mais cuidadoso pudesse ser efetivamente garantido, a ponto de não se chegar a uma situação de agressão. Sendo assim, encerrando o julgamento da ação direta de inconstitucionalidade 4.983, votou pela inconstitucionalidade da lei cearense que regulamentava a prática da vaquejada, o que fechou o placar em 6 X 5 pela procedência.

\section{DA PREVALENCIA DA NORMA QUE VEDA A CRUELDADE CONTRA OS ANIMAIS SOBRE A NORMA QUE GARANTE A MANIFESTAÇÃO CULTURAL}

Restou claro que o julgamento tratou da colisão de duas normas constitucionais no caso concreto: proteção da manifestação cultural popular (art. 215 da CF) e a proibição da crueldade a animais (art. 215, $\S 1^{\circ}$, inciso VII da CF).

Das alegações expostas por cada ministro do STF, conforme analisadas no tópico anterior, percebe-se que o embate entre as citadas normas constitucionais é, antes de tudo, um confronto entre paradigmas diferentes. Enquanto a norma que protege e garante a prática de manifestações culturais possui padrão antropocêntrico ${ }^{33}$, porque voltado para a realização do ser humano enquanto ser cultural, a norma que protege os animais de práticas cruéis, por sua vez, possui fundo

\footnotetext{
${ }^{33}$ Pode-se definir o antropocentrismo como a visão que "situa o homem como o senhor do universo, atribuindo-lhe poderes para utilizar os recursos naturais da forma que lhe aprouver. Neste contexto, os animais constituem apenas objeto do direito e só devem ser protegidos, de forma mediata, quando úteis para o atendimento dos interesses humanos." (BAHIA, Carolina Medeiros. O caso da farra do boi no Estado de Santa Catarina: colisão de direitos fundamentais. In: MOLINARO, Carlos Alberto; MEDEIROS, Fernanda Luiza Fontoura de; SARLET, Ingo Wolfgang; FENSTERSEIFER, Tiago (orgs.). A dignidade da vida e os direitos fundamentais para além dos humanos: uma discussão necessária. Belo Horizonte: Fórum, 2008. p. 401-402).
} 
biocêntrico $^{34}$, ou pós-humanista, porque voltado para proteção do animal enquanto indivíduo senciente, dotado de dignidade própria. ${ }^{35}$

Se é verdade que o antropocentrismo, paradigma $^{36}$ em que o Direito está enraizado (criado pelo ser humano e para o ser humano), tem alicerçado uma série de abusos contra os animais - tais como a exploração dos animais para fins alimentícios, para fins científicos, para a produção de produtos de beleza, para caça e pesca, entre outros, práticas notadamente cruéis -, por outro lado, não impede que se possa dar o primeiro passo no sentido de reconhecer que certas práticas não mais podem ser incentivadas na sociedade. Sobre esse aspecto, conforme pondera Vicente de Paula Ataide Junior, "o fato da Constituição permitir - e até fomentar - a pecuária e a pesca não faz retroceder seu avanço ético em reconhecer os animais não-humanos como sujeitos sencientes - e não como meras coisas ou bens sujeitos à arbitrária disposição humana."37

O caso da vaquejada, ao lado da farra do boi e da rinha de galo, ilustra que o sofrimento não pode ser aceito como lazer ou entretenimento humano, mesmo que seja uma prática secular de um povo. Em outras palavras, a manifestação cultural de um povo encontra um dos seus limites na dignidade animal. A vaquejada, por submeter os animais a sofrimento físico e mental, não pode ser tolerada: trata-se de um ambiente completamente hostil a esses animais os quais, cumpre lembrar, não são desportistas. Por isso, é possível afirmar que o interesse do animal em não sofrer é um interesse maior (porque envolve sua dignidade e sua qualidade de vida), se comparado ao interesse humano no caso (limitado a um entretenimento, embora economicamente vantajoso).

Não se trata de desmerecer ou discriminar uma cultura popular regional, alegação que paira na superficialidade do debate, mas de reconhecer que as manifestações culturais violentas aos animais não encontram amparo constitucional desde 1988. Não obstante a regra constitucional de proteção dos animais contra a crueldade humana, verifica-se que os argumentos trazidos para defender a continuidade da vaquejada, inclusive levantados pelos Ministros que votaram contra a declaração da inconstitucionalidade da lei cearense, são bastante frágeis em contraste com o argumento do sofrimento imposto aos animais.

$\mathrm{O}$ argumento de que, por ser uma manifestação cultural secular, isso torna a prática imune a críticas, é facilmente objetável. A cultura, pela qual um povo expressa seus valores e regras morais em determinado período histórico ${ }^{38}$, não é algo estático, mas algo que está em constante dinamismo, o que implica não apenas o abandono de certos valores, mas também a incorporação de novos. Não fosse assim, se não houvesse essa crítica aos valores do passado, não poderíamos

\footnotetext{
${ }^{34}$ Pode-se definir as teorias biocêntricas como aquelas que "retiram o homem da centralidade valorativa, pondo a vida em seu lugar. Caracterizam-se por atribuir uma dignidade própria aos elementos naturais, encarando-os como portadores de um valor intrínseco, e pela exigência de que seus interesses e valores sejam objeto de consideração jurídica ou moral. Parte dos autores chega, inclusive, a pleitear a inclusão dos animais na categoria de sujeitos de direito." (BAHIA, Carolina Medeiros. O caso da farra do boi no Estado de Santa Catarina: colisão de direitos fundamentais. In: MOLINARO, Carlos Alberto; MEDEIROS, Fernanda Luiza Fontoura de; SARLET, Ingo Wolfgang; FENSTERSEIFER, Tiago (orgs.). A dignidade da vida e os direitos fundamentais para além dos humanos: uma discussão necessária. Belo Horizonte: Fórum, 2008. p. 402).

${ }^{35}$ ATAIDE JUNIOR, Vicente de Paula. Introdução ao direito animal brasileiro. Revista Brasileira de Direito Animal, Salvador, v. 13, n. 3, p. 48-76, set./dez, 2018, p. 51. ISSN 2317-4552. Disponível em: < https://portalseer.ufba.br/index.php/RBDA/article/view/28768/17032>. Acesso $\quad$ em: 14 dez. 2019. DOI: http://dx.doi.org/10.9771/rbda.v13i3.28768.

${ }^{36}$ De acordo com Fritjof Capra, paradigma pode ser definido como "uma constelação de concepções, de valores, de percepções e de práticas compartilhados por uma comunidade, que dá forma a uma visão particular da realidade, a qual constitui a base da maneira como a comunidade se organiza" (CAPRA, Fritjof. A teia da vida: uma nova compreensão científica dos sistemas vivos. São Paulo: Cultrix, 2006. p. 25).

${ }^{37}$ ATAIDE JUNIOR, Vicente de Paula. Introdução ao direito animal brasileiro. Revista Brasileira de Direito Animal, Salvador, BA, v. 13, n. 3, p. 48-76, set./dez, 2018, p. 53. ISSN 2317-4552. Disponível em: < https://portalseer.ufba.br/index.php/RBDA/article/view/28768/17032>. Acesso $\quad$ em: 14 dez. 2019. DOI: http://dx.doi.org/10.9771/rbda.v13i3.28768.

${ }^{38}$ NOGUEIRA, Vânia Márcia Damasceno. Direitos fundamentais dos animais: a construção jurídica de uma titularidade para além dos seres humanos. Belo Horizonte: Arraes Editores, 2012. p. 197.
}

Revista de Direito Brasileira | Florianópolis, SC | v. 28 | n. 11 | p.80-103 | Jan./Abr. 2021 
evoluir enquanto sociedade. Conforme pondera Carolina Medeiros Bahia, o lado perigoso da cultura, ainda mais quando esta contempla práticas cruéis contra animais, "reside, principalmente, no impacto que representam para os valores da sociedade, contribuindo para a vulgarização da violência contra os animais, que passa a ser considerada como algo natural, perfeitamente tolerável." 39

Nem mesmo a "modernização" da vaquejada, com a introdução do protetor de cauda e o colchão de areia para a derrubada do boi, a fim de se aumentar o bem-estar animal, pode ser um argumento a favor da prática. É que esse suposto "conforto" não impede que os animais sofram antes, durante e após a vaquejada, a qual é definida oficialmente pela tração brusca da cauda do animal e sua posterior derrubada. Esses atos principais caracterizam a vaquejada, de modo que, se não pudesse ser mais realizada dessa maneira, não haveria vaquejada. ${ }^{40}$ Por isso, a vaquejada é intrinsecamente cruel porque, apesar das tentativas em garantir o bem-estar animal, invariavelmente essa prática provoca sofrimento aos animais.

Essa reflexão foi bem estruturada pelo Ministro Barroso:

No caso da vaquejada, a gravidade da ação contra o animal está tanto na tração e torção bruscas da cauda do boi, como também na queda dele. A força aplicada à cauda em sentido contrário à fuga, somada ao peso do animal, evidencia a gravidade da ação praticada contra o boi. Uma vez que a sua cauda não é mero adereço, mas sim a continuação de sua coluna vertebral, possuindo terminações nervosas, não é difícil concluir que o animal sinta dores. Também devido a seu elevado peso e à grande velocidade com que é tombado, é muito provável que os bois envolvidos sofram lesões ao serem levados ao chão. Além disso, não se trata de qualquer queda. Para que os vaqueiros pontuem, ou, para utilizar o jargão, para "valer o boi", devem tombar o animal de modo que ele exponha suas quatros patas. Evidentemente, para que isso seja possível, além de ser necessário imprimir maior força na tração e na torção de sua cauda, o animal deve cair lateralmente ou completamente voltado para o chão da pista de competição, o que, muito provavelmente, lhe causa traumas internos. ${ }^{41}$

Da mesma forma, apesar de ser bastante difundido pelos defensores da vaquejada, incabível o argumento no sentido de que a vaquejada gera empregos e que o impedimento de sua realização comprometeria uma substancial classe trabalhadora que depende da vaquejada para seu sustento. Esse argumento foi desconstruído pelo parecer do Procurador de Justiça do Estado de Alagoas, Valter José de Omena Acioly, o qual asseverou que os trabalhadores, tratadores e tangerinos são empregados precipuamente para cuidar dos cavalos e do gado, independentemente da realização da vaquejada. ${ }^{42}$

Assim, "não há uma defesa do emprego dos pequenos funcionários, há uma defesa de interesses econômicos que concentram a absoluta maioria do lucro nas mãos de pouquíssimos

\footnotetext{
${ }^{39}$ BAHIA, Carolina Medeiros. O caso da farra do boi no Estado de Santa Catarina: colisão de direitos fundamentais. In: MOLINARO, Carlos Alberto; MEDEIROS, Fernanda Luiza Fontoura de; SARLET, Ingo Wolfgang; FENSTERSEIFER, Tiago (orgs.). A dignidade da vida e os direitos fundamentais para além dos humanos: uma discussão necessária. Belo Horizonte: Fórum, 2008. p. 416

${ }^{40}$ Nas palavras do Ministro Luís Roberto Barroso: “[...] primeiro, porque a vaquejada é caracterizada pela 'puxada do boi' pela cauda. Sendo assim, qualquer regulamentação que impeça os vaqueiros de tracionarem e torcerem a cauda do boi descaracterizaria a própria vaquejada, fazendo com que ela deixasse de existir. Em segundo lugar, como a vaquejada também é caracterizada pela derrubada do boi dentro da chamada 'faixa', regulamentá-la de modo a proibir que o animal seja tombado também a descaracterizaria [...]." (STF, Pleno, ADI 4983, Relator Ministro MARCO AURÉLIO, julgado em 06/10/2016, publicado em 27/04/2017.)

${ }^{41}$ STF, Pleno, ADI 4983, Relator Ministro MARCO AURÉLIO, julgado em 06/10/2016, publicado em 27/04/2017.

${ }^{42}$ OLHAR ANIMAL. Vaquejada promove enriquecimento ilícito devido a condutas cruéis. Disponível em: <http://olharanimal.org/vaquejada-promove-enriquecimento-ilicito-devido-a-condutas-crueis-diz-procurador/> Acesso em: 04 dez. 2019.
}

Revista de Direito Brasileira | Florianópolis, SC | v. 28 | n. 11 | p.80-103 | Jan./Abr. 2021 
empresários." ${ }^{\text {"43 }}$ Em outras palavras, os defensores da vaquejada se utilizam do argumento da cultura para fazer desse evento, esportivo e de entretenimento, um grande negócio às custas do sofrimento dos animais, porém, esse sofrimento deve ter "consideração jurídica mesmo nas situações em que fortes interesses econômicos se façam presente." 44

Se compreendermos que o sofrimento é um mal que deve ser evitado e que esse sofrimento não pode ser mensurado (afinal, a dor do outro não é algo que pode ser medido, mas compreendido por uma série de sinais ou reações do ser perante a dor ${ }^{45}$ ), devemos reconhecer, como consequência, que a manifestação cultural da vaquejada, por implicar em sofrimento físico e mental aos animais, não encontra amparo constitucional. Nessa colisão de normas, deve prevalecer, portanto, a regra que veda a crueldade contra os animais sobre a norma que garante a prática de manifestação cultural, eis que "o avanço da etologia e a progressiva incorporação de valores éticos nas normas internacionais e do direito interno não permitem que hoje a questão da violência contra os animais deixe de ser levada em consideração, mesmo quando valores culturais estejam em jogo." ${ }^{46}$

Tendo em vista a regra constitucional de proibição da crueldade, elemento-chave da construção autônoma do Direito Animal no Brasil, também pode-se afirmar que a vaquejada configura crime na legislação infraconstitucional. De acordo com o artigo 32 da Lei 9.605/1998, configura-se crime "praticar ato de abuso, maus-tratos, ferir ou mutilar animais silvestres, domésticos ou domesticados, nativos ou exótico." Sendo a vaquejada uma atividade cruel, provocando sofrimento físico e mental, torna-se necessário fazer valer o teor do citado artigo, pois “atos praticados ainda que com caráter folclórico ou até histórico, como a 'farra do boi' estão abrangidos pelo art. 32 da Lei $n^{\circ}$ 9.605/98, e devem ser punidos não só quem os pratica, mas também, em coautoria, os que os incitam, de qualquer forma." 47

Esse panorama do debate em questão revela que grande parte da resistência contra a consideração moral e jurídica dos animais advém do fato de que ainda os considerarmos como meios aos fins humanos, como recursos, pelo que, naturalmente, são amplas as dificuldades no caminho diante do confronto dos interesses humanos com os interesses dos animais não-humanos. Esse confronto faz com que, numa situação em que se privilegia os interesses dos animais (e os animais sencientes possuem, ao menos, o interesse em não sofrer ${ }^{48}$ ), consideramos que estamos "perdendo direito" sobre "algo" 4950 que sempre foi tido como nosso, sendo essa a resistência

${ }^{43}$ OLHAR ANIMAL. Vaquejada promove enriquecimento ilícito devido a condutas cruéis. Disponível em: <http://olharanimal.org/vaquejada-promove-enriquecimento-ilicito-devido-a-condutas-crueis-diz-procurador/> Acesso em: 04 dez. 2019.

${ }^{44}$ BAHIA, Carolina Medeiros. Princípio da proporcionalidade nas manifestações culturais e na proteção da fauna. Curitiba: Juruá, 2006. p. 186.

${ }^{45}$ SINGER, Peter. Libertação animal. São Paulo: Editora WMF Martins Fontes, 2010. p. 17.

${ }^{46}$ BAHIA, Carolina Medeiros. O caso da farra do boi no Estado de Santa Catarina: colisão de direitos fundamentais. In: MOLINARO, Carlos Alberto; MEDEIROS, Fernanda Luiza Fontoura de; SARLET, Ingo Wolfgang; FENSTERSEIFER, Tiago (orgs.). A dignidade da vida e os direitos fundamentais para além dos humanos: uma discussão necessária. Belo Horizonte: Fórum, 2008. p. 416.

${ }^{47}$ MACHADO, Paulo Affonso Leme. Direito ambiental brasileiro. 21 ed. São Paulo: Malheiros, 2013 , p. 956.

${ }^{48}$ De acordo com Peter Singer, "a capacidade de sofrer e de sentir prazer é um pré-requisito para um ser ter algum interesse, uma condição que precisa ser satisfeita antes que possamos falar de interesse de maneira compreensível. [...] A capacidade de sofrer e de sentir prazer, entretanto, não apenas é necessária, mas também suficiente para que possamos assegurar que um ser possui interesses - no mínimo, o interesse de não sofrer." (SINGER, Peter. Libertação animal. São Paulo: Editora WMF Martins Fontes, 2010, p. 13).

${ }^{49}$ Nesse sentido, o movimento pelos direitos dos animais defende que os animais não são "algo" ou "coisas", mas sujeitos. Na visão de Gary L. Francione, “dizer que um ser é uma pessoa é meramente dizer que esse ser tem interesses moralmente significativos", de forma que, no caso dos animais, "sua condição de propriedade, entretanto, impediu que sua personalidade (personhood) fosse concretizada." (FRANCIONE, Gary L. Introdução aos direitos animais: seu filho ou o cachorro? Campinas: Editora Unicamp, 2013. p. 181).

${ }^{50} \mathrm{O}$ choque entre o interesse do ser humano (proprietário) e o interesse do animal (propriedade) revela que quase sempre o interesse daquele prevalecerá sobre o interesse deste. Nas palavras de Gary L. Francione, “o animal em questão é sempre um 'animal de estimação' ou 'pet', ou um animal 'de laboratório', ou um animal de 'caça', ou um

Revista de Direito Brasileira | Florianópolis, SC | v. 28 | n. 11 | p.80-103 | Jan./Abr. 2021 
enfrentada pelo movimento dos direitos animais, em uma sociedade que "coisificou" os animais para diversos fins humanos ${ }^{51}$.

Imperioso, portanto, o reconhecimento da dignidade de cada animal, derivada as sua senciência, como base de um novo campo do saber jurídico:

Para o Direito Animal, cada animal não-humano interessa, independentemente da sua função ou influência ecológica, esteja isolado ou em grupo, seja silvestre, doméstico ou domesticado, por causa da sua individualidade peculiar de ser vivo que sofre e que, por isso mesmo, merece respeito e consideração. ${ }^{52}$

Dessa maneira, conforme afirmado por Edna Cardozo Dias, "o empenho ético não pode estar desvinculado da justiça. A injustiça social está ligada à destruição da natureza e à violência contra os animais. A restauração da justiça e a proteção dos animais terão de vir juntas" 53 . À vista disso, a defesa dos direitos animais trata-se de uma questão de justiça aos seres mais vulneráveis, os quais, por não terem voz, têm seus interesses constantemente negociados e vilipendiados em benefício do ser humano. A consciência dos animais (e, por conseguinte, sua senciência), comprovada cientificamente ${ }^{54}$, faz com que devamos retirar esse véu da invisibilidade dos animais e questionar as mais variadas formas de exploração a que eles são submetidos.

A decisão do Supremo Tribunal Federal sobre a inconstitucionalidade da vaquejada tem uma força extraordinária, não só para abrir críticas ao paradigma antropocêntrico em que o direito está enraizado, mas também para fomentar o debate sobre a condição jurídica dos animais, discussão que já tem sido enfrentada no direito comparado. A Corte máxima do país, ao considerar, em sede de controle de constitucionalidade, que a norma constitucional que veda a crueldade contra os animais tem viés biocêntrico, verte para o necessário e inevitável reconhecimento da dignidade animal - o que significa que os animais não são coisas, mas sujeitos de direito ${ }^{55}$, pelo menos

animal 'para comida', ou um animal de 'rodeio', ou alguma outra forma de propriedade animal que existe para nosso uso e que só tem valor como um meio para os nossos fins. Não há realmente nenhuma escolha a ser feita entre o interesse do humano e interesse do animal porque a escolha já está predeterminada pelo status de propriedade do animal." (FRANCIONE, Gary L. Introdução aos direitos animais: seu filho ou o cachorro? Campinas: Editora Unicamp, 2013. p. 28)

${ }^{51}$ Nesse ponto, Gary L. Francione defende que o status de propriedade dos animais tem impedido que consideremos seus interesses como moralmente significativos. Nas palavras do autor, "como os animais são mera propriedade, geralmente temos permissão para ignorar seus interesses e para infligir-lhes a mais horrenda dor, sofrimento ou morte, quando essa atitude é economicamente vantajosa para nós." (FRANCIONE, Gary L. Introdução aos direitos animais: seu filho ou o cachorro? Campinas: Editora Unicamp, 2013. p. 27-28).

${ }^{52}$ ATAIDE JUNIOR, Vicente de Paula. Introdução ao direito animal brasileiro. Revista Brasileira de Direito Animal, Salvador, v. 13, n. 3, p. 48-76, set./dez, 2018, p. 52. ISSN 2317-4552. Disponível em: < https://portalseer.ufba.br/index.php/RBDA/article/view/28768/17032>. Acesso $\quad$ em: 14 dez. 2019. DOI: http://dx.doi.org/10.9771/rbda.v13i3.28768.

${ }_{53}^{53}$ DIAS, Edna Cardozo. A tutela jurídica dos animais. Belo Horizonte: Mandamentos, 2000. p. 345

${ }^{54}$ De acordo com a Declaração de Cambridge sobre a consciência em animais humanos e não-humanos, de 2012, "a ausência de um neocórtex não parece impedir que um organismo experimente estados afetivos. Evidências convergentes indicam que animais não humanos têm os substratos neuroanatômicos, neuroquímicos e neurofisiológicos de estados de consciência juntamente como a capacidade de exibir comportamentos intencionais. Consequentemente, o peso das evidências indica que os humanos não são os únicos a possuir os substratos neurológicos que geram a consciência. Animais não humanos, incluindo todos os mamíferos e as aves, e muitas outras criaturas, incluindo polvos, também possuem esses substratos neurológicos." (INSTITUTO HUMANITAS UNISINOS. Declaração de Cambridge sobre a consciência em animais humanos e não-humanos. Disponível em: $<$ http://www.ihu.unisinos.br/172-noticias/noticias-2012/511936-declaracao-de-cambridge-sobre-a-consciencia-emanimais-humanos-e-nao-humanos >. Acesso em: 07 dez. 2019)

${ }^{55}$ Nesse ponto, de acordo com Heron Gordilho, "a regra constitucional que proíbe a prática de atividades que submetemos animais a crueldade traz em seu bojo o princípio da dignidade animal, o que nos obriga a reconhecê-los como sujeitos de diretos fundamentais básicos" (GORDILHO, Heron José de Santana. Abolicionismo animal. Salvador: Evolução, 2008. p. 162). 
"sujeitos do direito fundamental à existência digna" $" 5657$ ou dos direitos fundamentais de $4^{\mathrm{a}}$ dimensão.

\section{O EFEITO BACKLASH E A PROIBIÇÃO DA VAQUEJADA}

A decisão do Supremo Tribunal Federal no caso vaquejada demonstra que a mais alta Corte do país continua assumindo uma posição de vanguarda na proteção dos interesses dos animais em relação a certas condutas humanas, especialmente quando a atividade humana está calcada no âmbito cultural. ${ }^{58}$ Como se viu, a vaquejada é uma prática regional que, muito embora provoque sofrimento aos animais, movimenta uma expressiva quantidade de dinheiro e recursos, razão pela qual, seus defensores buscam a perpetuação da prática.

Por essa razão, a jurisdição constitucional enfrentou a resistência de grupos variados que, encontrando seus representantes no Congresso Nacional, buscaram meios políticos para "sobrepor" a decisão da Corte Suprema. ${ }^{59}$ Buscou-se, em outras palavras, uma reação legislativa como forma de superação da decisão constitucional, fenômeno conhecido como efeito backlash. ${ }^{60}$

Ao analisar as decisões judiciais que tocaram em temas polêmicos, como a questão racial, pena de morte, aborto e casamento entre pessoas do mesmo sexo, Michael Klarman, jurista norteamericano, notou que o conteúdo mais liberal dessas decisões (ou seja, pelo fím da segregação racial em escolas, pelo fim da pena de morte, pela garantia do direito ao aborto e pela possibilidade do casamento homoafetivo), provocou uma indesejada reação política de setores conservadores, que buscaram meios de reverter os efeitos daquelas decisões, notadamente contrárias aos seus interesses. Esse fenômeno de reversão jurisprudencial por reação legislativa foi chamado pelo citado jurista como efeito backlash (expressão que pode ser traduzida ao português como "retrocesso" ou "o ato de retroceder"61).

De acordo com Ana Conceição Barbuda Sanches Guimarães Ferreira:

The backlash, portanto, como acontecimento de reação pode provocar o que se denomina claramente como o fenômeno de Reversão Jurisprudencial por Reação Legislativa, que se constitui claramente como o fenômeno pelo qual, após referendado por um Tribunal, uma opção interpretativa em favor de um ponto polêmico de grande conteúdo sócio-político, insurge-se o poder político que, em autêntico ato de reação, contraria a decisão judicial proferida, tendo por objetivo

\footnotetext{
${ }^{56}$ ATAIDE JUNIOR, Vicente de Paula. Introdução ao direito animal brasileiro. Revista Brasileira de Direito Animal, Salvador, v. 13, n. 3, p. 48-76, set./dez, 2018, p. 53. ISSN 2317-4552. Disponível em: < https://portalseer.ufba.br/index.php/RBDA/article/view/28768/17032>. $\quad$ Acesso $\quad$ em: $14 \quad$ dez. 2019. DOI: http://dx.doi.org/10.9771/rbda.v13i3.28768.

${ }^{57}$ Sobre a relação estreita entre senciência, dignidade e direito fundamental: ATAIDE JUNIOR, Vicente de Paula. Introdução ao direito animal brasileiro. Revista Brasileira de Direito Animal, Salvador, v. 13, n. 3, p. 48-76, set./dez, 2018, p. 50-51. ISSN 2317-4552. Disponível el <https://portalseer.ufba.br/index.php/RBDA/article/view/28768/17032>. Acesso $\quad$ em: $14 \quad$ dez. 2019. DOI: http://dx.doi.org/10.9771/rbda.v13i3.28768.

${ }^{58}$ Note-se que, mais recentemente, o Supremo Tribunal Federal decidiu que o sacrifício de animais em rituais religiosos de origem africana não destoa a regra da proibição da crueldade (STF, Pleno, RE 494.601-RS, Relator Ministro Edson Fachin, julgado em 28/3/2019).

${ }^{59}$ Confira-se, por exemplo: TV BRASIL. Milhares de vaqueiros ocuparam hoje a Esplanada dos Ministérios em protesto. Disponível em: <https://www.youtube.com/watch?v=TayQcOPdiYU>. Acesso em: 22 mar. 2018.

${ }^{60}$ Cf. LIMA, George Marmelstein. Efeito backlash da jurisdição constitucional: reações políticas à atuação judicial. Disponível em: <https://direitosfundamentais.net/2015/09/05/efeito-backlashda-jurisdicao-constitucional-reacoespoliticas-a-atuacao-judicial/>. Acesso em: 22 mar. 2020.

${ }^{61}$ FERREIRA, Ana Conceição Barbuda Sanches Guimarães. Direito animal em xeque: precedentes judiciais e reação legislativa. Curitiba: Juruá, 2018. p. 200.
}

Revista de Direito Brasileira | Florianópolis, SC | v. 28 | n. 11 | p.80-103 | Jan./Abr. 2021 
sanar, impossibilitar e até conceder por sua ação uma outra interpretação diametralmente oposta a constituída no julgado do Tribunal. ${ }^{62}$

$\mathrm{Na}$ visão de Michael Klarman, por vezes os tribunais reivindicam direitos antes que o Poder Legislativo esteja pronto para fazê-lo, o que faz desencadear, em verdade, um efeito oposto, ou seja, um retrocesso político que acaba por retardar um movimento social. ${ }^{63}$

No caso Brown v. Board of Education of Topeka (1954), por exemplo, em que a Suprema Corte norte-americana declarou ser inconstitucional a segregação de alunos brancos e negros em escolas primárias, desencadeou-se, após esse julgado, uma política de retrocesso no sul dos Estados Unidos, criando-se, em curto tempo, um ambiente próprio para a violência, fazendo, inclusive, com que políticos de posições mais segregacionistas fossem eleitos. ${ }^{64}$

A decisão da Suprema Corte contra a pena de morte, no caso Furman v. Georgia (1972), por sua vez, resultou, de forma irônica, no aumento do apelo popular pela pena capital, com 35 estados norte-americanos promulgando, rapidamente, novos estatutos de pena de morte. ${ }^{65}$

Da mesma forma, a decisão da Suprema Corte a favor do direito ao aborto, no caso Roe v. Wade (1973), fez surgir um forte movimento a favor da vida, que remodelou a política americana subsequente, tornando o aborto mais dificultoso. ${ }^{66}$ No que se refere ao casamento homossexual, a Suprema Corte do Estado do Hawaii, no ano de 1993, considerou inconstitucional uma lei local que reservava o casamento apenas entre pessoas de sexos opostos ${ }^{67}$ e a Suprema Corte de Massachusetts, no ano de 2003 (caso Goodridge v. Department of Public Health), decidiu a favor do casamento entre pessoas do mesmo sexo. Essas decisões geraram, respectivamente, na promulgação da Lei de Defesa do Casamento de $1996^{68}$ e na edição de emendas constitucionais, em mais de 25 estados, proibindo expressamente o casamento homoafetivo. ${ }^{670}$

O processo de reversão jurisprudencial por reação legislativa pode ser mais ou menos sintetizado na seguinte ordem:

(1) Em uma matéria que divide a opinião pública, o Judiciário profere uma decisão liberal, assumindo uma posição de vanguarda na defesa dos direitos fundamentais.

(2) Como a consciência social ainda não está bem consolidada, a decisão judicial

\footnotetext{
${ }^{62}$ FERREIRA, Ana Conceição Barbuda Sanches Guimarães. Direito animal em xeque: precedentes judiciais e reação legislativa. Curitiba: Juruá, 2018. p. 199.

${ }^{63}$ KLARMAN, Michael. Marriage equality and political backlash. New York Times, 2015. Disponível em: <https://www.nytimes.com/roomfordebate/2013/03/26/civil-rights-decisions-in-courts-or-legislatures/marriageequality-and-political-backlash>. Acesso em: 22 mar. 2020.

${ }^{64}$ KLARMAN, Michael. Courts, social change and political backlash. In: Hart Lecture at Georgetown Law Center, March 31, $2011 \quad$ - $\quad$ Speaker's $\quad$ Note, p. $4 . \quad$ Disponível em: <https://scholarship.law.georgetown.edu/cgi/viewcontent.cgi?article=1001\&context=hartlecture>. Acesso em: 22 mar. 2020.

${ }^{65}$ KLARMAN, Michael Marriage equality and Political Backlash. New York Times, 2015. Disponível em: <https://www.nytimes.com/roomfordebate/2013/03/26/civil-rights-decisions-in-courts-or-legislatures/marriageequality-and-political-backlash> Acesso em: 22 mar. 2020.

${ }^{66}$ KLARMAN, Michael. Marriage equality and political backlash. New York Times, 2015. Disponível em: <https://www.nytimes.com/roomfordebate/2013/03/26/civil-rights-decisions-in-courts-or-legislatures/marriageequality-and-political-backlash>. Acesso em: 22 mar. 2020.

67 UOL NOTÍCIAS. Há 40 anos, pedido de casamento gay era negado nos EUA. Disponível em: <https://noticias.uol.com.br/ultimas-noticias/afp/2015/06/26/grandes-datas-na-conquista-do-casamento-gay-noseua.htm> Acesso em: 20 mar. 2019.

${ }^{68}$ Lei federal que somente considerava válido o casamento entre homem e mulher. Em 2013, no entanto, a Suprema Corte dos Estados Unidos declarou como inconstitucional essa disposição, por não abranger o casamento homossexual.

${ }^{69}$ KLARMAN, Michael Marriage equality and Political Backlash. New York Times, 2015. Disponível em: <https://www.nytimes.com/roomfordebate/2013/03/26/civil-rights-decisions-in-courts-or-legislatures/marriageequality-and-political-backlash>. Acesso em: 22 mar. 2020.

${ }^{70}$ Somente em 2015 a Suprema Corte dos Estados Unidos legalizou o casamento entre pessoas do mesmo sexo em todo o território norte-americano.
}

Revista de Direito Brasileira | Florianópolis, SC | v. 28 | n. 11 | p.80-103 | Jan./Abr. 2021 
é bombardeada com discursos conservadores inflamados, recheados de falácias com forte apelo emocional. (3) A crítica massiva e politicamente orquestrada à decisão judicial acarreta uma mudança na opinião pública, capaz de influenciar as escolhas eleitorais de grande parcela da população. (4) Com isso, os candidatos que aderem ao discurso conservador costumam conquistar maior espaço político, sendo, muitas vezes, campeões de votos. (5) Ao vencer as eleições e assumir o controle do poder político, o grupo conservador consegue aprovar leis e outras medidas que correspondam à sua visão de mundo. (6) Como o poder político também influencia a composição do Judiciário, já que os membros dos órgãos de cúpula são indicados politicamente, abre-se um espaço para mudança de entendimento dentro do próprio poder judicial. (7) Ao fim e ao cabo, pode haver um retrocesso jurídico capaz de criar uma situação normativa ainda pior do que a que havia antes da decisão judicial, prejudicando os grupos que, supostamente, seriam beneficiados com aquela decisão. ${ }^{71}$

Esse fenômeno político, mesmo considerando que objetiva superar a jurisprudência da mais alta Corte de Justiça do país, não é propriamente antijurídico e até se justifica em termos de teoria política democrática. ${ }^{72}$ Os efeitos vinculantes no controle de constitucionalidade não atingem, em regra, o Poder Legislativo, mas apenas os demais órgãos do Poder Judiciário e todos os do Poder Executivo. ${ }^{73}$ Dessa feita, o Poder Legislativo pode reagir para inovar a ordem jurídica, seja por meio de emenda constitucional, seja por intermédio de leis ordinárias ${ }^{74}$, as quais, no entanto, também podem ser objetos de controle de constitucionalidade.

A decisão do Supremo Tribunal Federal declarando a inconstitucionalidade da lei cearense que regulamentava a prática da vaquejada deu-se em 6 de outubro de 2016. Pouco mais de um mês após essa decisão, entrou em vigor Lei 13.364, de 29 de novembro de 2016, a qual, de acordo com o artigo $1^{\circ}$, "eleva a vaquejada, o rodeio, bem como suas respectivas expressões artístico-culturais, à condição de manifestação cultural nacional e de patrimônio cultural imaterial."

Começava, com essa lei, a produção da eficácia backlash à jurisdição constitucional do caso vaquejada.

Também alguns dias após a decisão da Suprema Corte, foi proposta emenda constitucional (PEC 50/2016), de autoria do Senador Otto Alencar (PSB/BA), visando a alterar a Constituição Federal para incluir mais um parágrafo ao artigo 225 do texto constitucional, ressalvando que "não se consideram cruéis as práticas desportivas que utilizem animais, desde que sejam manifestações culturais, conforme o $\S 1^{\circ}$ do art. 215 desta Constituição Federal, registradas como bem de natureza imaterial integrante do patrimônio cultural brasileiro, devendo ser regulamentadas por lei específica que assegure o bem-estar dos animais envolvidos." A PEC, votada em cada casa do Congresso Nacional, em dois turnos, atingiu o número suficientes de votos para sua aprovação, tornando-se, em 06 de junho de 2017, com a citada redação, a Emenda Constitucional 96. ${ }^{75}$

\footnotetext{
${ }^{71}$ LIMA, George Marmelstein. Efeito backlash da jurisdição constitucional: reações políticas à atual judicial. Disponível em: <https://direitosfundamentais.net/2015/09/05/efeito-backlash-da-jurisdicao-constitucional-reacoespoliticas-a-atuacao-judicial/>. Acesso em: 22 mar. 2019.

72 Sobre o tema, ver: CHUEIRI, Vera Karam de; MACEDO, José Arthur Castillo de. Teorias constitucionais progressistas, backlash e vaquejada. Sequência, Florianópolis, n. 80, p. 123-150, dez. 2018. Disponível em: <http://www.scielo.br/scielo.php?script=sci_arttext\&pid=S2177-70552018000300123\&lng=en\&nrm=iso>. Acesso em: 7 abr. 2020. DOI: https://doi.org/10.5007/2177-7055.2018v39n80p123.

${ }^{73}$ FERREIRA, Ana Conceição Barbuda Sanches Guimarães. Direito animal em xeque: precedentes judiciais e reação legislativa. Curitiba: Juruá, 2018. p. 198

${ }^{74}$ FERREIRA, Ana Conceição Barbuda Sanches Guimarães. Direito animal em xeque: precedentes judiciais e reação legislativa. Curitiba: Juruá, 2018. p. 205.

75 Já foram protocoladas, no Supremo Tribunal Federal, duas Ações Diretas de Inconstitucionalidade para questionar a Emenda Constitucional 96/2017: ADIn 5758, distribuída, em 13/6/2017, à relatoria do Ministro Dias Tóffoli; ADIn 5772, proposta pelo Procurador-Geral da República, distribuída, em 12/9/2017, à relatoria do Ministro Luís Roberto Barroso.
} 
Parece um pouco mais do que evidente que a alteração constitucional não tem o condão de mudar a natureza das coisas ou, como nas palavras de Paulo Affonso Leme Machado, "a crueldade não se transforma em benignidade só por efeito de uma lei, ainda que constitucional, pois uma lei não tem força para transmudar 'água em vinho', rompendo a ordem natural das coisas." 76

Não é preciso muito para concluir pela inconstitucionalidade da Emenda Constitucional 96/2017. O poder de reforma constitucional conhece limitações materiais, consubstanciadas nas cláusulas pétreas do art. $60, \$^{\circ}$, da Constituição, dentre as quais os direitos e garantias individuais. A regra da proibição da crueldade, prevista no art. $225, \S 1^{\circ}$, VII da Constituição, personificou o direito fundamental animal à existência digna (de quarta dimensão, pós-humanista), de natureza individual, posta a salvo de práticas humanas cruéis. Como direito fundamental individual, ainda que não-humano, é imune ao poder constituinte derivado. O processo legislativo da emenda constitucional sequer poderia ter sido iniciado. As práticas cruéis contra animais estão constitucionalmente interditadas. Não importa se a prática é desportiva, se é manifestação cultural, se é registrada como bem de natureza imaterial integrante do patrimônio cultural brasileiro ou se existe lei local regulamentando a atividade. Caso a prática implique em crueldade contra animais está proibida pela ordem constitucional vigente, ainda que a lei local procure paliativos para reduzir a dor, a angústia e o sofrimento dos animais envolvidos. A prática cruel não comporta gradações. A crueldade é, de qualquer forma, incompatível com os valores adotados pela Constituição. No julgamento da ADIn 4983, o STF reconheceu, por meio de dados empíricos, que a prática da vaquejada é intrinsecamente cruel, não havendo como existir vaquejada sem crueldade. ${ }^{77}$

É de se assinalar que as decisões definitivas de mérito do Supremo Tribunal Federal, em sede de controle concentrado de constitucionalidade, produzem eficácia contra todos e efeito vinculante, relativamente aos demais órgãos do Poder Judiciário e à administração pública direta e indireta, nas esferas federal, estadual e municipal (art. 102, §2 $2^{\circ}$, Constituição, com redação dada pela EC 45/2004). Constituem, por isso, precedentes obrigatórios e vinculantes (art. 927, I, CPC), dotados de eficácia erga omnes. A inobservância do precedente autoriza o manejo da reclamação constitucional (art. 102, I, 1, Constituição), para a garantia da autoridade da decisão judicial (art. 988, II e III, CPC), dirigida ao próprio tribunal do qual emanou a decisão a ser garantida, no caso, o Supremo Tribunal Federal (art. $988, \S 1^{\circ}, \mathrm{CPC}$ ). Ao menos desde a vigência do Código de Processo Civil brasileiro de 2015, a reclamação para garantir a observância de decisão do Supremo Tribunal Federal, em controle concentrado de constitucionalidade, também compreende "a aplicação indevida da tese jurídica e sua não aplicação aos casos que a ela correspondam” (art. 988, $\S 4^{\circ}, \mathrm{CPC}$ ), pelo que se tem, agora, na jurisdição constitucional brasileira, a adoção da teoria da transcendência dos fundamentos ou motivos determinantes.

A tese jurídica fixada na ADIN 4983 foi de que a crueldade é inerente à vaquejada e, portanto, a vaquejada discrepa da norma inconstitucional. Ainda que a jurisdição constitucional do STF, com a ADIN 4983, tenha sofrido o efeito backlash, com a aprovação da Emenda Constitucional 96/2017, é certo que, quanto à vaquejada, não há como retroceder. ${ }^{78} 79$ Em outras palavras, a própria prática da vaquejada é inconstitucional, não apenas a lei cearense que tentava

\footnotetext{
${ }^{76}$ MACHADO, Paulo Affonso Leme. Direito ambiental brasileiro. 25 ed. São Paulo: Malheiros, 2017. p. 172.

${ }^{77}$ ATAIDE JUNIOR, Vicente de Paula. Introdução ao direito animal brasileiro. Revista Brasileira de Direito Animal, Salvador, v. 13, n. 3, p. 48-76, set./dez, 2018, p. 54. ISSN 2317-4552. Disponível em: <https://portalseer.ufba.br/index.php/RBDA/article/view/28768/17032〉. Acesso $\quad$ em: 14 dez. 2019. DOI: http://dx.doi.org/10.9771/rbda.v13i3.28768.

${ }^{78}$ ATAIDE JUNIOR, Vicente de Paula. Introdução ao direito animal brasileiro. Revista Brasileira de Direito Animal, Salvador, v. 13, n. 3, p. 48-76, set./dez, 2018, p. 58-59. ISSN 2317-4552. Disponível em: < https://portalseer.ufba.br/index.php/RBDA/article/view/28768/17032>. Acesso em: 14 dez. 2019. DOI: http://dx.doi.org/10.9771/rbda.v13i3.28768.

${ }^{79}$ GORDILHO, Heron José de Santana; FIGUEIREDO, Francisco José Garcia. A vaquejada à luz da Constituição Federal. Revista de Biodireito e Direito dos Animais, v. 2, p. 78-96, 2017. p. 93.
} 
escamotear a sua crueldade ínsita. A vaquejada, por todo o país, está proibida pela jurisdição constitucional, mesmo após a entrada em vigor da referida emenda constitucional.

Por fim, como complemento argumentativo, merece nota que o Instituto do Patrimônio Histórico e Artístico Nacional (IPHAN), apoiado no Decreto 3.551/2000 (que institui o Registro de Bens Culturais de Natureza Imaterial que constituem Patrimônio Cultural Brasileiro), pronunciou-se, à época, no sentido de ser o único órgão com a competência para catalogar uma prática como patrimônio cultural imaterial brasileiro, e, com essa prerrogativa, não reconheceu a vaquejada como tal. ${ }^{80}$ Torna-se questionável o ato legislativo que, ao ignorar uma série de procedimentos técnicos específicos, expressamente delineados no citado Decreto, reconhece uma atividade como patrimônio cultural imaterial.

\section{CONCLUSÕES}

Algumas conclusões da pesquisa podem ser sumariadas:

(1) a jurisprudência do Supremo Tribunal Federal, desde a promulgação da Constituição Federal de 1988, é sensível à temática animal, valorizando e fazendo valer a regra da proibição da crueldade contra animais (art. 225, $\S 1^{\circ}$, VII, in fine, CF);

(2) mesmo com o recente julgamento do RE 494.601-RS, fixando a tese jurídica no sentido que "É constitucional a lei de proteção animal que, a fim de resguardar a liberdade religiosa, permite o sacrifício ritual de animais em cultos de religiões de matriz africana", não se desnaturou a farta jurisprudência de proteção animal desenvolvida desde os anos noventa, a partir da proibição da farra do boi, em Santa Catarina;

(3) com o julgamento da ADIN 4983, reconhecendo a inconstitucionalidade da lei do Estado Ceará sobre a vaquejada, percebe-se a abertura da jurisprudência do STF para perspectivas de vanguarda nos campos do Direito Ambiental e Direito Animal, como, por exemplo, a referência biocêntrica - e não antropocêntrica - na interpretação do art. 225 da CF, bem como a autonomia da regra da proibição da crueldade em relação à preservação do meio ambiente ou do equilíbrio ecológico, o que autoriza reconhecer a própria autonomia do Direito Animal em relação ao Direito Ambiental; em outras palavras, constata-se ligeira abertura da jurisprudência do STF aos influxos do pós-humanismo;

(4) o desenvolvimento do Direito Animal, especialmente no âmbito da jurisdição constitucional, depende de um constante diálogo com a Medicina Veterinária e ciências afins, tendo sempre, como diretriz fundamental, a proteção da dignidade individual dos animais;

(5) com o efeito backlash ao julgamento da ADIN 4983, especialmente com a aprovação da Emenda Constitucional 96/2017, não se reputa autorizada a prática da vaquejada no país, a qual, conforme reconhecido no caso, é intrinsecamente cruel e discrepa da norma constitucional; a vaquejada continua proibida, cabendo, além de outros instrumentos processuais, a reclamação para os casos em que ela for consentida e realizada;

(6) o parágrafo sétimo, incluído ao art. 225 da Constituição, pela Emenda 96/2017, é inconstitucional, por ultrapassar as limitações materiais ao poder reformador, vulnerando cláusulas

\footnotetext{
${ }^{80}$ Nesse sentido: “O ato legislativo pode reconhecer a relevância da expressão cultural, como feito, sem, contudo, categorizar tal bem como Patrimônio Cultural Imaterial, resultado que decorre unicamente da aplicação do Registro de Bens Culturais Imateriais. [...] O Iphan é a instância do Poder Público Federal que conduz e deve conduzir os processos de reconhecimento de bens como Patrimônio Cultural do Brasil. [...] Desta forma, o Iphan confirma o apoio e a valorização de todas as manifestações culturais do país, mas ressalta que a declaração do título de "Patrimônio Cultural" é atribuição exclusiva deste Instituto. Além disso, a aprovação de Leis dessa natureza pelo Legislativo Federal provocará um esvaziamento da política de preservação do patrimônio cultural imaterial já consolidada no âmbito do Iphan e que é modelo para diversos países, como um dos sistemas mais avançados do mundo.” (IPHAN. "Posicionamento do IPHAN sobre o reconhecimento do Rodeio e da Vaquejada como manifestação cultural pelo Legislativo Federal". Disponível em: <https://oholocaustoanimal.files.wordpress.com/2016/12/iphanvaquejadas-e-rodeios.pdf $>$. Acesso em: 14 dez. 2019)
}

Revista de Direito Brasileira | Florianópolis, SC | v. 28 | n. 11 | p.80-103 | Jan./Abr. 2021 
constitucionais pétreas, por menoscabar os direitos fundamentais de $4^{\mathrm{a}}$ dimensão (ou direitos fundamentais pós-humanistas), concernentes à dignidade dos animais não-humanos e a sua imunidade contra práticas humanas cruéis; é de rigor a procedência das ADIN's 5758 e 5772, ainda pendentes de julgamento do STF;

(7) o precedente tirado do julgamento da ADIN 4983 pode ser utilizado para coibir práticas análogas à vaquejada - como os rodeios - dada a transcendência dos motivos determinantes, conforme expressamente previsto pelo art. $988, \S 4^{\circ}$, do $\mathrm{CPC}$, inclusive por meio da ação civil pública, proposta na comarca do local do evento.

\section{REFERÊNCIAS}

AGÊNCIA DE NOTÍCIAS DE DIREITOS ANIMAIS. Conselho Federal de Medicina Veterinária se posiciona contra vaquejadas. Disponível em: < https://www.anda.jor.br/2016/10/conselho-federal-demedicina-veterinaria-se-posiciona-contra-vaquejadas/> Acesso em: 17 nov. 2019.

AGÊNCIA DE NOTÍCIAS DE DIREITOS ANIMAIS. Vaquejada tem de ser proibida imediatamente. Disponível em: <https://www.anda.jor.br/2016/11/vaquejada-tem-de-ser-proibidaimediatamente-diz-veterinaria-da-usp/>. Acesso em: 21 nov. 2019.

ATAIDE JUNIOR, Vicente de Paula. Introdução ao direito animal brasileiro. Revista Brasileira de Direito Animal, Salvador, v. 13, n. 3, p. 48-76, set./dez, 2018. ISSN 2317-4552. Disponível em: <https://portalseer.ufba.br/index.php/RBDA/article/view/28768/17032>. Acesso em: 14 dez. 2019. DOI: http://dx.doi.org/10.9771/rbda.v13i3.28768.

ATAIDE JUNIOR, Vicente de Paula. A afirmação histórica do Direito Animal no Brasil. Revista Internacional de Direito Ambiental. v. VIII, n. 22, p. 295-332. jan./abr. 2019.

ATAIDE JUNIOR, Vicente de Paula (coord.). Comentários ao Código de Direito e Bem-Estar Animal do Estado da Paraíba: a positivação dos direitos fundamentais animais. Curitiba: Juruá, 2019.

ASSOCIAÇÃO BRASILEIRA DE MEDICINA VETERINÁRIA LEGAL. Nota pública quanto à inconstitucionalidade da vaquejada. Disponível em: <http://www.abmvl.org.br/singlepost/2016/10/24/ABMVL-\%E2\%80\%93-NOTA-P\%C3\%9ABLICA-QUANTO-\%C3\%80INCONSTITUCIONALIDADE-DA-VAQUEJADA>. Acesso em: 19 nov. 2019.

ASSOCIAÇÃO BRASILEIRA DE VAQUEJADA. História da Vaquejada. Disponível em: <http://www.abvaq.com.br/institucional>. Acesso em: 10 nov. 2019.

ASSOCIAÇÃO BRASILEIRA DE VAQUEJADA. Regulamento Geral. Disponível em: https://abvaq.com.br/regulamento>. Acesso em: 11 nov. 2019.

BAHIA, Carolina Medeiros. O caso da farra do boi no Estado de Santa Catarina: colisão de direitos fundamentais. In: MOLINARO, Carlos Alberto; MEDEIROS, Fernanda Luiza Fontoura de; SARLET, Ingo Wolfgang; FENSTERSEIFER, Tiago (orgs.). A dignidade da vida e os direitos fundamentais para além dos humanos: uma discussão necessária. Belo Horizonte: Fórum, 2008.

BAHIA, Carolina Medeiros. Princípio da proporcionalidade nas manifestações culturais e na proteção da fauna. Curitiba: Juruá, 2006. 
BITTENCOURT, Mario. 'O boi teve o rabo arrancado': proibição da vaquejada abre polêmica. G1, Bahia. Disponível em: 〈http://g1.globo.com/bahia/noticia/2016/11/o-boi-teve-o-rabo-arrancadoproibicao-da-vaquejada-abre-polemica.html>. Acesso em: 19 nov. 2019.

CAPRA, Fritjof. A teia da vida: uma nova compreensão científica dos sistemas vivos. São Paulo: Cultrix, 2006.

CONSELHO FEDERAL DE MEDICINA VETERINÁRIA. Desmistificar a vaquejada. Disponível em: < http://portal.cfmv.gov.br/noticia/index/id/5799/secao/6 >. Acesso em: 11 nov. 2019.

CHUEIRI, Vera Karam de; MACEDO, José Arthur Castillo de. Teorias constitucionais progressistas, backlash e vaquejada. Sequência, Florianópolis, n. 80, p. 123-150, dez. 2018. Disponível em: $<$ http://www.scielo.br/scielo.php?script=sci_arttext\&pid=S217770552018000300123\&lng=en\&nrm= iso>. Acesso em: 7 abr. 2020. DOI: https://doi.org/10.5007/2177-7055.2018v39n80p123.

DIAS, Edna Cardozo. A tutela jurídica dos animais. Belo Horizonte: Mandamentos, 2000.

FERREIRA, Ana Conceição Barbuda Sanches Guimarães. Direito animal em xeque: precedentes judiciais e reação legislativa. Curitiba: Juruá, 2018. p. 200.

FRANCIONE, Gary L. Introdução aos direitos animais: seu filho ou o cachorro? Campinas: Editora Unicamp, 2013. p. 181.

GORDILHO, Heron José de Santana. Abolicionismo animal. Salvador: Evolução, 2008.

GORDILHO, Heron José de Santana; FIGUEIREDO, Francisco José Garcia. A vaquejada à luz da Constituição Federal. Revista de Biodireito e Direito dos Animais, v. 2, p. 78-96, 2017.

INSTITUTO HUMANITAS UNISINOS. Declaração de Cambridge sobre a consciência em animais humanos e não-humanos. Disponível em: <http://www.ihu.unisinos.br/172-noticias/noticias2012/511936-declaracao-de-cambridge-sobre-a-consciencia-em-animais-humanos-e-nao-humanos > . Acesso em: 07 dez. 2019.

IPHAN. "Posicionamento do IPHAN sobre o reconhecimento do Rodeio e da Vaquejada como manifestação cultural pelo Legislativo Federal". Disponível em:

<https://oholocaustoanimal.files.wordpress.com/2016/12/iphan-vaquejadas-e-rodeios.pdf $>$. Acesso em: 14 dez. 2019.

KLARMAN, Michael. Marriage equality and political backlash. New York Times, 2015. Disponível em: <https://www.nytimes.com/roomfordebate/2013/03/26/civil-rights-decisions-in-courts-orlegislatures/marriage-equality-and-political-backlash>. Acesso em: 18 de mar. de 2019.

KLARMAN, Michael. Courts, social change and political backlash. In: Hart Lecture at Georgetown Law Center, March 31, 2011 - Speaker's Note, p. 4. Disponível em:

<https://scholarship.law.georgetown.edu/cgi/viewcontent.cgi? article=1001\&context=hartlecture $>$. Acesso em: 19 mar. 2019.

LEITÃO, Geuza. A voz dos sem voz. Fortaleza: INESP, 2002. p. 23. 
LIMA, George Marmelstein. Efeito backlash da jurisdição constitucional: reações políticas à atuação judicial. Disponível em: <https://direitosfundamentais.net/2015/09/05/efeito-backlashda-jurisdicaoconstitucional-reacoes-politicas-a-atuacao-judicial/>. Acesso em: 22 mar. 2018.

LOPES, K. R. F.; BATISTA, J.; DIAS, R. V. C; BLANCO, B. S.. Influência das competições de vaquejada sobre os parâmetros indicadores de estresse em equinos. Ciência Animal Brasileira, (UFG), v. 10, p. 545-550, 2009.

MACHADO, Paulo Affonso Leme. Direito ambiental brasileiro. 21 ed. São Paulo: Malheiros, 2013.

MACHADO, Paulo Affonso Leme. Direito ambiental brasileiro. 25 ed. São Paulo: Malheiros, 2017.

NOGUEIRA, Vânia Márcia Damasceno. Direitos fundamentais dos animais: a construção jurídica de uma titularidade para além dos seres humanos. Belo Horizonte: Arraes Editores, 2012.

OLHAR ANIMAL. Vaquejada promove enriquecimento ilícito devido a condutas cruéis. Disponível em: <http://olharanimal.org/vaquejada-promove-enriquecimento-ilicito-devido-a-condutas-crueis-dizprocurador/> Acesso em: 04 dez. 2019.

SENADO FEDERAL. Associação acredita poder mudar decisão do STF. Disponível em: <https://www12.senado.leg.br/emdiscussao/edicoes/vaquejada/vaquejada/associacao-acredita-podermudar-decisao-do-stf $>$. Acesso em: 11 nov. 2019.

SINGER, Peter. Libertação animal. São Paulo: Editora WMF Martins Fontes, 2010.

STF, Pleno, ADI 4983, Relator Ministro MARCO AURÉLIO, julgado em 06/10/2016, publicado em 27/04/2017.

TV BRASIL. Milhares de vaqueiros ocuparam hoje a Esplanada dos Ministérios em protesto. Disponível em: <https://www.youtube.com/watch?v=TayQcOPdiYU>. Acesso em: 22 mar. 2019.

UOL NOTÍCIAS. Há 40 anos, pedido de casamento gay era negado nos EUA. Disponível em: <https://noticias.uol.com.br/ultimas-noticias/afp/2015/06/26/grandes-datas-na-conquista-docasamento-gay-nos-eua.htm> Acesso em: 20 mar. 2019.

VIDEOPAR. Protetor de cauda para uso na vaquejada. Disponível em: <https://www.videopar.com.br/artigos/43-Protetor-de-Cauda-para-uso-na-Vaquejada>. Acesso em: 20 nov. 2019. 